\title{
Testing of a Danish growth model for barley, turnip rape and timothy in Finnish conditions
}

\author{
ARI ILOLA ${ }^{1}$, ESKO ELOMAA ${ }^{2}$ and SEPPO PULLI ${ }^{3}$ \\ I Department of Crop Science, Agricultural Research Centre \\ $S F-31600$ Jokioinen, Finland \\ 2 Technical Department, Finnish Meteorological Institute \\ P.O. Box 503 \\ SF-00101 Helsinki, Finland \\ ${ }^{3}$ Department of Plant Breeding, Agricultural Research Centre \\ SF-31600 Jokioinen, Finland
}

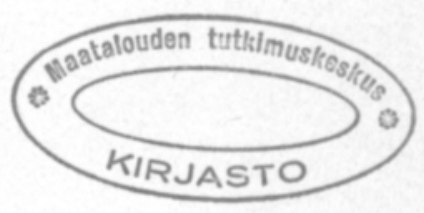

\begin{abstract}
The biological and meteorological data were collected at Jokioinen in 1982-87. Potential and actual (water limited) production of dry matter were simulated using a Danish WATCROS model for spring barley, spring turnip rape and timothy grass.

The most important data of the biological programme comprised weekly measurements of the crop surface (GAI), dry matter yield, root growth, soil water content and yield analyses of the harvest. All these measurements were performed for both irrigated and non-irrigated plots. The needed meteorological parameters for the daily simulation of the dry matter yield were global radiation, air temperature and precipitation.

The simulated dry matter production results with the WATCROS model were generally higher than those measured. In order to obtain a better fit into the Finnish climatic and soil conditions, the Finnish model should take soil water conditions and efficient use of photosynthetically active radiation into consideration.
\end{abstract}

Index words: Finland, crop growth, crop production, simulation, barley, turnip rape, timothy

\section{Contents}

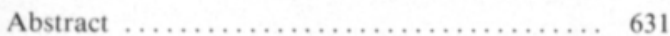

Symbols

1. INTRODUCTION

2. THE EXPERIMENTAL FIELD
2.1. Layout of the field 633

2.2. Soil properties .............. 633

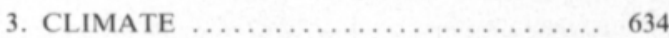

3.1. General description of the meteorological measurements 
3.2. Solar radiation $\ldots \ldots \ldots \ldots \ldots \ldots \ldots .637$

3.3. Air and soil temperature .......... 637

3.4. Air humidity .................. 639

3.5. Wind speed and direction .......... 639

3.6. Potential evapotranspiration ......... 639

3.7. Precipitation ................... 640

3.8. Precipitation deficit ............. 640

4. THE BIOLOGICAL PROGRAMME ..... 640

5. PLANT GROWTH AND DEVELOPMENT 641

5.1 Crop surface $\ldots \ldots \ldots \ldots \ldots \ldots \ldots \ldots \ldots 641$

5.2. Root growth ................... 641

5.3. Dry matter production ........... 643

6. RESULTS OF THE END HARVESTINGS 644

6.1. Barley and turnip rape ............ 644

6.2. Timothy .................... 644
7. THE MODEL ........................ 645

7.1. Simulation of the crop area index ..... 645

7.2. Actual evapotranspiration .......... 646

7.3. Potential gross production ......... 650

7.4. Respiration and net plant production .. 651

7.5. Water limited plant production ...... 653

8. RESULTS AND DISCUSSION ......... 653

8.1. Barley and turnip rape ........... 653

8.2. Timothy ................... 656

9. CONCLUSIONS $\ldots \ldots \ldots \ldots \ldots \ldots \ldots, 658$

ACKNOWLEDGEMENTS $\ldots \ldots \ldots \ldots \ldots \ldots 658$

REFERENCES ....................... 659

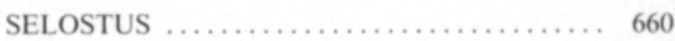

\section{Symbols}

Symbols in the text marked with an asterisk denote capacities or potential values.

A Gross $\mathrm{CO}_{2}$ single leaf assimilation, photosynthesis

$A_{\mathrm{m}}$ Gross $\mathrm{CO}_{2}$ single leaf assimilation, photosynthesis, at light saturation

A Albedo visible radiation (400-700 nm), light

c Factor converting stored energy into structural plant dry matter

C Crop area index

d Maximum effective root depth

D Slope of the saturation vapour pressure curve versus temperature

D Precipitation deficit

e Vapour pressure

e, Saturation water vapour pressure

$\mathrm{e}_{\mathrm{sa}} \quad$ Saturation vapour pressure, at dry-air temperature

$e_{\mathrm{sw}} \quad$ Saturation vapour pressure, at wet-bulb temperature

E Evapotranspiration

$\mathrm{E}_{\mathrm{c}} \quad$ Evapotranspiration from the crop

$\mathrm{E}_{\mathrm{c}, \mathrm{g}}$ Evapotranspiration from the crop, green active area

$E_{c, y}$ Evaporation from the crop, yellow inactive area

E, Evaporation from the soil

$\mathrm{E}_{\mathrm{T}}$ Transpiration from the crop

G Crop area index, green active area

$\mathrm{G}_{\mathrm{g}} \quad$ Ground heat flux

$\mathrm{G}_{\mathrm{m}} \quad$ Maximum green area index

$\mathrm{H}$ Harvest index

I Irrigation

k Extinction coefficient of PAR

$\mathrm{K}$ Extinction coefficient of net radiation

L Latent heat of the vaporization of water

m Constant p Gross photosynthetic efficiency

P Precipitation

$\mathrm{P}_{\mathrm{g}} \quad$ Gross production

$\mathrm{P}_{\mathrm{n}} \quad$ Net production

$r_{g} \quad$ Growth respiration coefficient

$r_{m} \quad$ Maintenance respiration coefficient

$\mathbf{R}_{\mathrm{g}} \quad$ Growth respiration

$\mathbf{R}_{\mathrm{m}} \quad$ Maintenance respiration

$\mathbf{R}_{n} \quad$ Net radiation above grass

$\mathrm{S}$ Radiative flux density below the downward accumulated GAI (Green area index)

$\mathrm{S}_{\mathrm{abs}}$ Absorption of photosynthetic active radiation (PAR)

$\mathrm{S}_{\mathrm{i}} \quad$ Global radiation

$\mathrm{S}_{\mathrm{n}} \quad$ Radiative flux above the canopy

$\mathrm{S}_{\mathrm{v}}$ Visible radiation $(400-700 \mathrm{~nm})$ fraction of the global radiation $(300-2500 \mathrm{~nm})$

$\mathrm{S}_{1} \quad$ Topsoil water capasity

$\mathrm{S}_{\text {r }} \quad$ Root zone water capacity

$\mathrm{S}_{1} \quad$ Storage, intercepted water

$\mathrm{S}_{1, g}$ Storage, intercepted water, green active area

$\mathrm{S}_{1, y}$ Storage, intercepted water, yellow inactive area

$t$ time

$\mathrm{t}_{\mathrm{a}} \quad$ Dry-air temperature, ${ }^{\circ} \mathrm{C}$

$\mathrm{t}_{\mathrm{w}} \quad$ Wet-bulb temperature, ${ }^{\circ} \mathrm{C}$

$\mathrm{t}_{\mathrm{s}}$ Soil temperature, ${ }^{\circ} \mathrm{C}$

$v \quad$ Wind speed

W Total dry matter in the field

$W_{h} \quad$ Harvested dry matter yield

$\mathrm{W}_{\mathrm{L}} \quad$ Non-harvested dry matter (stubble, root, etc. mass loss)

$\mathrm{Y} \quad$ Yellow area index

$\mathrm{Y}_{\mathrm{p}} \quad$ Psychrometric constant 


\section{Introduction}

The joint Nordic project on the effect of climatological factors on crop growth and production was started in 1982. The research programme was planned by a working group of the agricultural meteorology of Section I of the Association of the Agricultural Scientists of Scandinavia. It was carried out in Denmark in 1982-85, in Norway in 1982-86 and in Finland in 1982-87. It was funded by the national authorities (in Finland by the Academy of Finland).

Field experiments of climatic field (the experimental field) were carried out in 1982-87 at Jokioinen, in SW-Finland, to test Danish growing models for various crops. The main aim of the project was to calculate potential and water-limited crop growth and production. Danish models constructed by ASLYNG and HANSEN (1982), in modified forms, were used as the basis of calculations. The models are based on experimental results of the weekly dry matter and crop area index (CAI) measurements and daily measurements of the climatological and hydrological factors of the experimental field. The models are simple enough to be used for routine monitoring of changes during the growing season and of the production of various crops. Another aim of the project was to test the Danish models.

After six years of experimental work and one year of research work, results can be given for spring barley (barley), spring turnip rape (turnip rape) and timothy grass. Some details concerning the project have been pubiished previously (ElomaA and Pulli 1985, SAArinen et al. 1986, ElomaA et al. 1986, ElomaA 1987).

\section{The experimental field}

\subsection{Layout of the field}

Three species, barley, turnip rape and perennial grass timothy, were tested in irrigated and non-irrigated plots (Fig. 3.1.). Detailed crop and soil observations were made for each of six plots from 1982 to 1987.

\subsection{Soil properties}

The topsoil $(0-20 \mathrm{~cm})$ was classified as heavy clay with $7-11 \%$ organic matter. The subsoil was defined as heavy clay lacking $\mathrm{C}$ compounds and phosphorous, but rich in magnesium and calcium (Tables 2.1, 2.2). Chemical analyses of the plots were performed annually since 1983 (Table 2.3). Plots A and C were limed in spring 1986 and 1987.

In 1984, the water retention capacity of the soil profiles was studied, and the entire soil moisture retention curve was determined. The water capacity usable by plants was $15-20$ percent of volume, depending on the plot and soil depth (Table 2.4).

The hydraulic conductivity of the soil was measured with the MSU (Michigan State University) method in 1987 (SAAVALAINEN and Rintanen 1986). Normal reliable ( $R>$ 0.95 ) measurements were $0.15-0.38$ (mean $0.22) \mathrm{cm}$ water in one hour. The heterogeneity of the plots and the depth of the soil as well as pore holes caused some variation between the measurements $\left(0.02-4.83 \mathrm{~cm} \mathrm{~h}^{-1}\right)$.

During the growth period, the soil moisture content of each plot was monitored weekly. In 1982 soil moisture was measured with gypsum blocks at five soil depths. Irrigated plots 
Table 2.1. Chemical analysis and physical properties of soil layers in 1985.

\begin{tabular}{|c|c|c|c|c|c|c|c|c|c|c|}
\hline \multirow[t]{2}{*}{ Plot } & \multirow{2}{*}{$\begin{array}{c}\text { Depth } \\
\mathrm{cm}\end{array}$} & \multirow[t]{2}{*}{$\mathrm{pH}$} & \multicolumn{4}{|c|}{$\mathrm{mg} / \mathrm{l}$} & \multicolumn{3}{|c|}{ per cent } & \multirow{2}{*}{$\begin{array}{c}\text { Bulk } \\
\text { Density } \\
\mathrm{g} \mathrm{cm}^{-3}\end{array}$} \\
\hline & & & $\mathrm{Ca}$ & K & $\mathrm{Mg}$ & $\mathrm{P}$ & $\mathrm{C}$ & $\begin{array}{l}\text { Org. }{ }^{1} \\
\text { matter }\end{array}$ & $\mathrm{N}^{\prime}$ & \\
\hline \multirow[t]{4}{*}{ Al } & $00-20$ & 5.7 & 2175 & 265 & 542 & 7.0 & 3.6 & 7.9 & 0.20 & 1.25 \\
\hline & $20-40$ & 5.8 & 2600 & 310 & 1250 & 1.9 & 1.8 & 3.8 & 0.04 & 1.31 \\
\hline & $40-70$ & 6.7 & 2750 & 255 & 1775 & 0.6 & 0.4 & 2.5 & - & 1.37 \\
\hline & $70-100$ & 6.8 & 2600 & 305 & 1850 & 0.8 & 0.3 & 3.0 & - & 1.32 \\
\hline \multirow[t]{4}{*}{$\mathrm{A} 2$} & $00-20$ & 5.8 & 2375 & 225 & 585 & 5.4 & 3.3 & 7.2 & 0.23 & 1.34 \\
\hline & $20-40$ & 5.9 & 2375 & 185 & 825 & 2.1 & 1.9 & 3.8 & 0.09 & 1.35 \\
\hline & $40-70$ & 6.4 & 3325 & 245 & 1850 & 1.0 & 0.6 & 3.1 & - & 1.32 \\
\hline & $70-100$ & 6.9 & 3000 & 287 & 1775 & 1.4 & 0.3 & 2.8 & - & 1.32 \\
\hline \multirow[t]{4}{*}{ B1 } & $00-20$ & 5.6 & 2250 & 282 & 515 & 6.6 & 4.2 & 8.8 & 0.26 & 1.27 \\
\hline & $20-40$ & 5.8 & 2250 & 277 & 877 & 3.8 & 3.0 & 7.2 & 0.04 & 1.29 \\
\hline & $40-70$ & 6.2 & 2375 & 225 & 1500 & 1.0 & 1.3 & 3.5 & - & 1.32 \\
\hline & $70-100$ & 6.7 & 2550 & 267 & 1825 & 0.8 & 0.3 & 2.8 & - & 1.35 \\
\hline \multirow[t]{4}{*}{ B2 } & $00-20$ & 5.5 & 2275 & 350 & 475 & 8.1 & 4.6 & 10.4 & 0.23 & 1.33 \\
\hline & $20-40$ & 5.6 & 1625 & 187 & 615 & 1.7 & 2.0 & 9.3 & 0.04 & 1.30 \\
\hline & $40-70$ & 6.4 & 3000 & 240 & 1800 & 0.5 & 0.4 & 3.6 & - & 1.31 \\
\hline & $70-100$ & 6.6 & 2850 & 265 & 1750 & 0.6 & 0.3 & 2.7 & - & 1.35 \\
\hline \multirow[t]{4}{*}{$\mathrm{Cl}$} & $00-20$ & 5.7 & 2450 & 385 & 600 & 7.4 & 4.6 & 9.4 & 0.26 & 1.17 \\
\hline & $20-40$ & 5.7 & 2275 & 340 & 1200 & 3.3 & 2.7 & 3.4 & 0.07 & 1.32 \\
\hline & $40-70$ & 6.5 & 2775 & 245 & 2000 & 0.7 & 0.4 & 3.1 & - & 1.31 \\
\hline & $70-100$ & 7.0 & 2625 & 270 & 2025 & 0.9 & 0.3 & 2.8 & - & 1.32 \\
\hline \multirow[t]{4}{*}{$\mathrm{C} 2$} & $00-20$ & 5.7 & 2450 & 385 & 610 & 7.1 & 4.6 & 10.0 & 0.26 & 1.18 \\
\hline & $20-40$ & 5.8 & 1875 & 245 & 790 & 2.2 & 2.7 & 4.9 & 0.07 & 1.27 \\
\hline & $40-70$ & 6.2 & 2775 & 237 & 1925 & 1.1 & 0.6 & 3.3 & - & 1.27 \\
\hline & $70-100$ & 7.0 & 2925 & 275 & 2125 & 1.2 & 0.3 & 2.8 & - & 1.33 \\
\hline
\end{tabular}

KEY: $1=$ Year 1986; Plot $1=$ irrigated, 2 =non-irrigated

were watered (plots 1, Fig. 3.1) if the soil moisture content available for plants was below $50 \%$ (Table 2.5). Gypsum blocks were not reliable after winter, and soil moisture could not be measured in 1983. In 1984 soil water content was measured gravimetrically, taking soil samples from each plot, to a depth of $50 \mathrm{~cm}$. Because 1984 was a rainy year, no irrigation was needed. In 1985 the soil water content was measured both gravimetrically and with the neutron scattering method, BASC depth moisture probe (Table 2.6).

\section{Climate}

\subsection{General description of the meteorological measurements}

Solar radiation and wind direction were measured at the top of a meteorological mast situated beside the experimental field. Profiles of wind speed and dry-air and wet-bulb temperatures were also measured at the mast. Short-wave solar radiation, air and soil temperature, air humidity and soil moisture were measured for each experimental plot (Fig. 3.1). In 1984 gypsum blocks were removed for soil moisture measurements; they were

Table 2.2. Mechanical analysis of the soil layers in the experimental field in 1987.

\begin{tabular}{lrrrr}
\hline $\begin{array}{l}\text { Depth } \\
\mathrm{cm}\end{array}$ & \multicolumn{4}{c}{ Weight $\%$} \\
\cline { 2 - 5 } & Clay & Silt & $\begin{array}{r}\text { Fine } \\
\text { Sand }\end{array}$ & $\begin{array}{c}\text { Coarse } \\
\text { Sand }\end{array}$ \\
\hline $00-20$ & 63.0 & 13.8 & 20.0 & 3.2 \\
$20-40$ & 71.8 & 11.1 & 13.1 & 4.0 \\
$40-70$ & 75.0 & 10.1 & 13.8 & 1.1 \\
$70-100$ & 87.2 & 3.1 & 8.6 & 1.1 \\
\hline
\end{tabular}


Table 2.3. Chemical analysis of the tillage layer of the plots.

\begin{tabular}{|c|c|c|c|c|c|c|}
\hline \multirow[t]{2}{*}{ Plot } & \multirow[t]{2}{*}{ Year } & \multirow[t]{2}{*}{$\mathrm{pH}$} & \multicolumn{4}{|c|}{$\mathrm{mg} / \mathrm{l}$} \\
\hline & & & $\mathrm{Ca}$ & K & $\mathrm{Mg}$ & $\mathrm{P}$ \\
\hline \multirow[t]{5}{*}{ Al } & 1983 & 6.3 & 2590 & 310 & 621 & 6.3 \\
\hline & 1984 & 6.2 & 2330 & 325 & 625 & 6.0 \\
\hline & 1985 & 5.7 & 2175 & 265 & 542 & 7.0 \\
\hline & 1986 & 6.2 & 2279 & 262 & 615 & 5.0 \\
\hline & 1987 & 6.2 & 2945 & 292 & 628 & 6.7 \\
\hline \multirow[t]{5}{*}{$\mathrm{A} 2$} & 1983 & 6.1 & 2660 & 300 & 631 & 5.4 \\
\hline & 1984 & 6.1 & 2555 & 288 & 683 & 4.9 \\
\hline & 1985 & 5.8 & 2375 & 225 & 585 & 5.4 \\
\hline & 1986 & 5.8 & 2255 & 334 & 498 & 8.0 \\
\hline & 1987 & 6.2 & 3304 & 333 & 752 & 9.2 \\
\hline \multirow[t]{5}{*}{ BI } & 1983 & 5.9 & 2390 & 338 & 616 & 5.7 \\
\hline & 1984 & 5.9 & 2165 & 345 & 572 & 6.2 \\
\hline & 1985 & 5.6 & 2250 & 282 & 515 & 6.6 \\
\hline & 1986 & 5.7 & 2190 & 294 & 478 & 8.8 \\
\hline & 1987 & 6.1 & 2787 & 307 & 822 & 5.7 \\
\hline \multirow[t]{5}{*}{ B2 } & 1983 & 5.9 & 2320 & 326 & 515 & 6.0 \\
\hline & 1984 & 6.0 & 2190 & 329 & 553 & 5.2 \\
\hline & 1985 & 5.5 & 2275 & 350 & 475 & 8.1 \\
\hline & 1986 & 5.7 & 2090 & 285 & 449 & 7.9 \\
\hline & 1987 & 6.0 & 2846 & 296 & 892 & 5.6 \\
\hline \multirow[t]{5}{*}{$\mathrm{Cl}$} & 1983 & 6.1 & 2680 & 348 & 727 & 6.7 \\
\hline & 1984 & 5.8 & 2135 & 338 & 683 & 4.5 \\
\hline & 1985 & 5.7 & 2450 & 385 & 600 & 7.4 \\
\hline & 1986 & 5.8 & 2303 & 296 & 714 & 7.5 \\
\hline & 1987 & 6.0 & 3030 & 419 & 714 & 7.0 \\
\hline \multirow[t]{5}{*}{$\mathrm{C} 2$} & 1983 & 5.9 & 2480 & 331 & 595 & 6.9 \\
\hline & 1984 & 5.9 & 2255 & 348 & 590 & 5.7 \\
\hline & 1985 & 5.7 & 2450 & 370 & 610 & 7.1 \\
\hline & 1986 & 6.2 & 2734 & 260 & 673 & 6.2 \\
\hline & 1987 & 6.2 & 2962 & 345 & 691 & 7.2 \\
\hline
\end{tabular}

replaced by pyranometers to measure the reflected short-wave radiation of each plot.

A calculating data logger, an Autodata Ten/5 made by Acurex (USA), was used for data-logging. A one-minute scanning interval was used to measure the meteorological vari-
Table 2.4. Soil capasity for available water $\mathrm{mm}$ in different soil layers for $1 \mathrm{~cm}, 25 \mathrm{~cm}$ and effective root depth.

\begin{tabular}{lrcccc}
\hline Plot & & \multicolumn{4}{c}{ Soil Depth $(\mathrm{cm})$} \\
\cline { 3 - 6 } & & $0-25$ & $25-50$ & $50-75$ & $0-75$ \\
\hline A & $1 \mathrm{~cm}$ & 1.6 & 1.6 & 1.5 & \\
& $25 \mathrm{~cm}$ & 40 & 40 & 37 & 117 \\
B & $1 \mathrm{~cm}$ & 1.7 & 1.7 & 1.6 & \\
& $25 \mathrm{~cm}$ & 42 & 42 & 40 & 124 \\
C & $1 \mathrm{~cm}$ & 2.0 & 1.8 & 1.6 & \\
& $25 \mathrm{~cm}$ & 50 & 45 & 40 & 135 \\
\hline
\end{tabular}

Table 2.5. Irrigation schedule in $1982-87$.

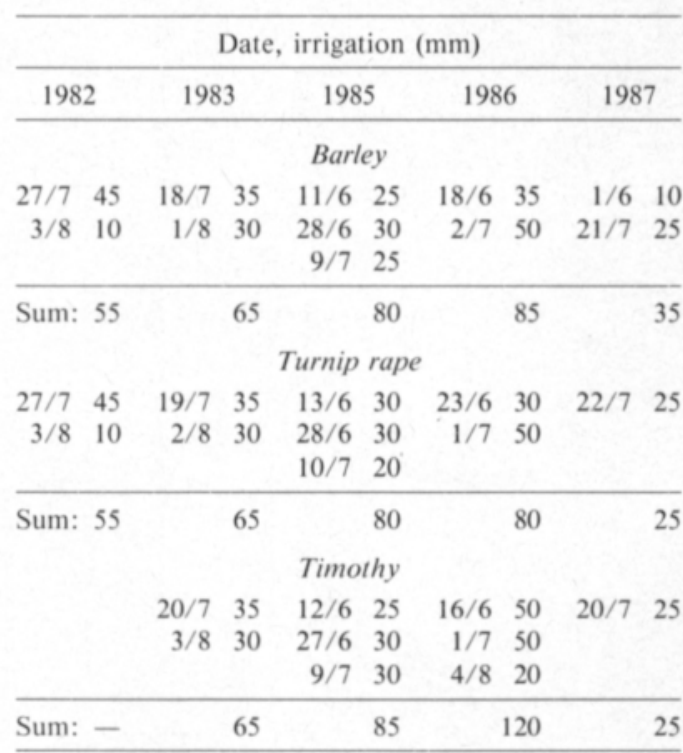

ables. Hourly mean values were stored in the C-cassettes of an MFE 2500 tape recorder. The C-cassettes were converted to magnetic tapes for further analysis.

The climatological measurement results for the experimental field were compared to the

Table 2.6. Measuring depths of soil moisture in 1982-87.

\begin{tabular}{lll}
\hline Year & Management & Depth $(\mathrm{cm})$ \\
\hline $1982-1983$ & Gypsum Block & $-10,-20,-30,-50,-100$ \\
$1984-1987$ & Gravimetrically & $-10,-20,-30,-50$ \\
$1985-19871$ & Neutron Scattering & $-10,-20,-30,-40,-50$, \\
& Method (BASC) & $-60,-80,-100$ \\
\hline
\end{tabular}

KEY: $1=$ Year $1987:-15,-30,-45,-60,-75,-90$ 
Fig. 3.1.

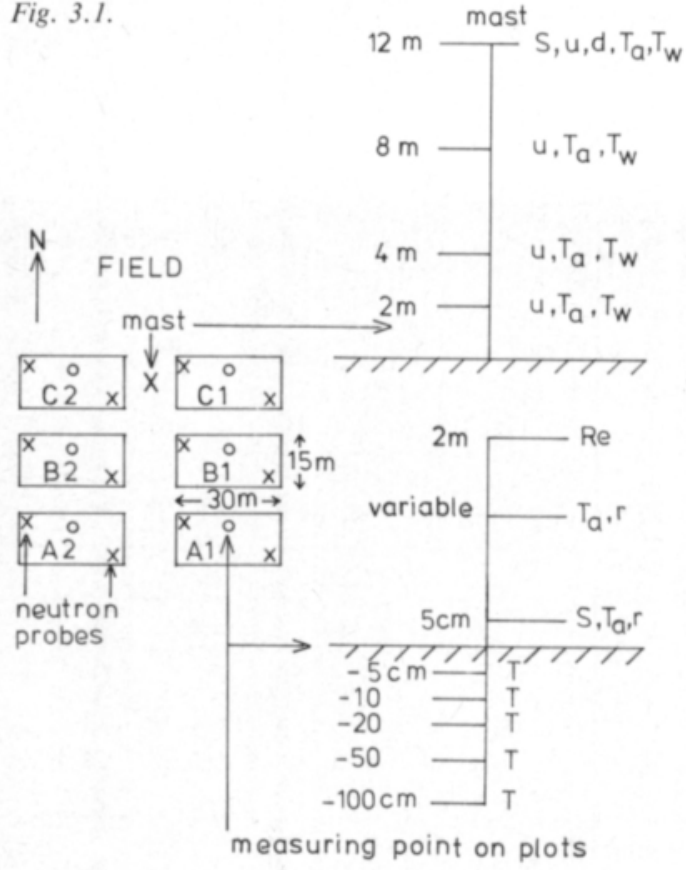

Fig. 3.2.

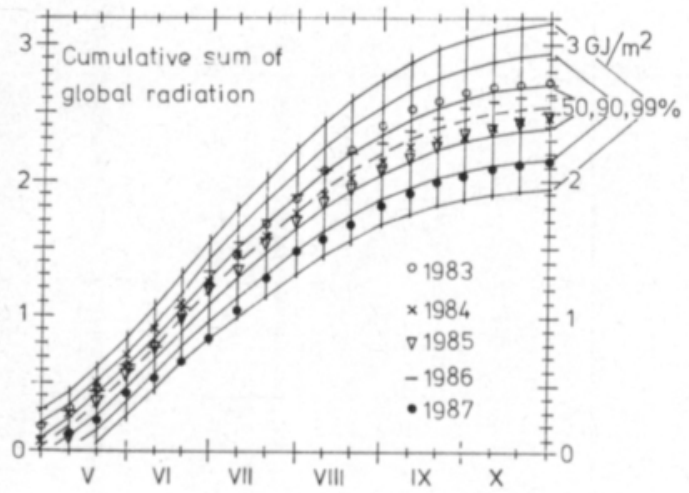

Fig. 3.3.

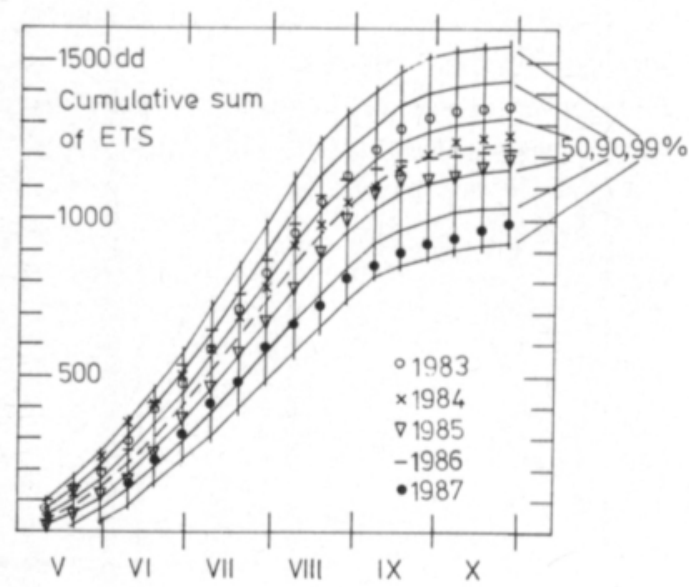

Fig. 3.4.

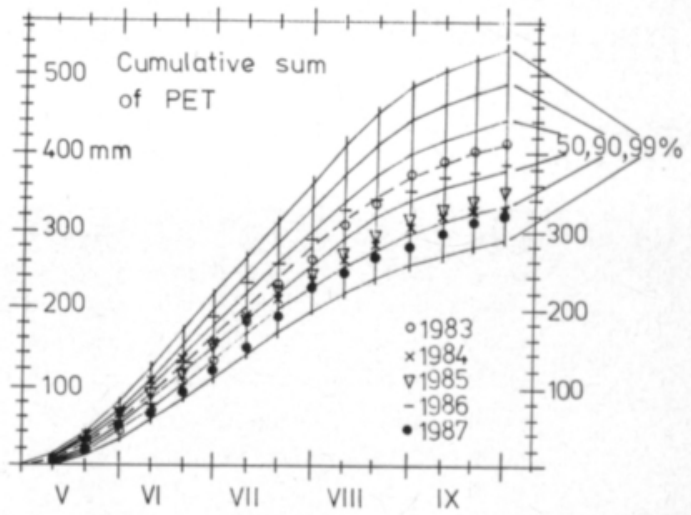

Fig. 3.5.

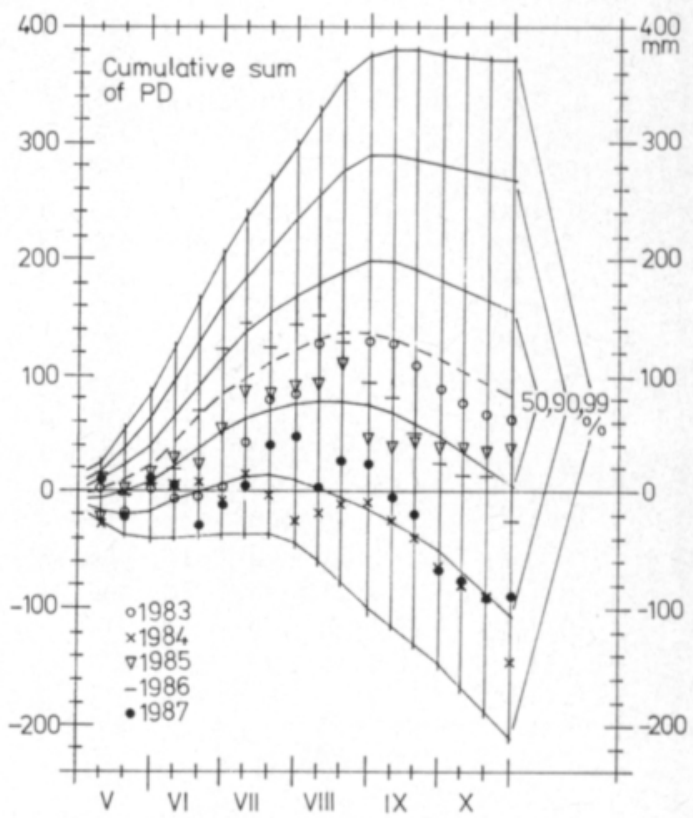

Fig. 3.1. Meteorological observations on the experimental field.

$\mathrm{S}=$ global radiation

$\mathrm{u}=$ wind speed

$\mathrm{d}=$ wind direction

$T_{\mathrm{a}}=$ dry-air temperature

$\mathrm{T}_{\mathrm{w}}=$ wet-bulb temperature

$\mathbf{R}_{e}=$ reflected short-wave radiation

$\mathrm{r}=$ relative humidity

$\mathrm{T}=$ soil temperature

Fig. 3.2. Cumulative sum of global radiation at Jokioinen (medians and probability limits).

Fig. 3.3. Cumulative sum of effective growing temperature at Jokioinen (medians and probability limits).

Fig. 3.4. Cumulative sum of potential evapotranspiration at Jokioinen (medians and probability limits).

Fig. 3.5. Cumulative sum of precipitation deficit at Jokioinen (medians and probability limits). 
Table 3.1. Monthly cumulative sums of global radiation $\left(\mathrm{MJ} / \mathrm{m}^{2}\right)$ at Jokioinen Observatory in April-October.

\begin{tabular}{lcccccc}
\hline & $\begin{array}{c}\text { Mean } \\
1957-1983\end{array}$ & 1983 & 1984 & 1985 & 1986 & 1987 \\
\hline April & 391 & 309 & 412 & 419 & 343 & 464 \\
May & 578 & 453 & 601 & 585 & 544 & 436 \\
June & 639 & 581 & 592 & 585 & 680 & 416 \\
July & 573 & 638 & 535 & 556 & 578 & 642 \\
August & 441 & 537 & 455 & 391 & 377 & 356 \\
September & 242 & 240 & 180 & 264 & 247 & 217 \\
October & 105 & 93 & 95 & 123 & 109 & 108 \\
\hline
\end{tabular}

Table 3.2. Mean air temperature $\left({ }^{\circ} \mathrm{C}\right)$ at Jokioinen Observatory in April-October.

\begin{tabular}{|c|c|c|c|c|c|c|}
\hline & $\begin{array}{c}\text { Mean } \\
1957-1984\end{array}$ & 1983 & 1984 & 1985 & 1986 & 1987 \\
\hline April & 2.0 & 4.8 & 4.2 & 0.5 & 2.1 & 2.4 \\
\hline May & 8.7 & 11.0 & 12.6 & 8.6 & 10.5 & 7.6 \\
\hline June & 14.0 & 13.3 & 13.1 & 13.2 & 16.3 & 12.1 \\
\hline July & 15.6 & 16.6 & 14.8 & 15.3 & 16.2 & 14.8 \\
\hline August & 14.2 & 15.0 & 13.8 & 15.5 & 12.9 & 11.7 \\
\hline September & 9.3 & 11.0 & 9.2 & 8.9 & 6.4 & 8.4 \\
\hline October & 4.4 & 5.4 & 6.6 & 6.4 & 5.2 & 6.4 \\
\hline
\end{tabular}

Table 3.3. Mean soil temperature $\left(-10 \mathrm{~cm},{ }^{\circ} \mathrm{C}\right)$ at Jokioinen Observatory in May-September.

\begin{tabular}{lcrrrrr}
\hline & $\begin{array}{c}\text { Mean } \\
1957-1983\end{array}$ & 1983 & 1984 & 1985 & 1986 & 1987 \\
\hline May & 7.5 & 9.1 & 9.9 & 4.7 & 8.5 & 5.8 \\
June & 13.8 & 13.7 & 14.3 & 12.6 & 14.4 & 11.7 \\
July & 16.0 & 16.2 & 16.2 & 15.2 & 16.3 & 15.8 \\
August & $(15.1)$ & 15.2 & 15.5 & 15.6 & 14.7 & 13.2 \\
September & $(10.8)$ & 11.8 & 10.6 & 10.3 & 8.5 & 9.8 \\
& $(1957-1970)$ & & & & & \\
\hline
\end{tabular}

measurements made by the Meteorological Observatory at Jokioinen, $1 \mathrm{~km}$ from the experimental field.

\subsection{Solar radiation}

Short-wave solar radiation was measured with KIPP \& ZONEN pyranometers, which were calibrated with the pyranometer used at the nearby Meteorological Observatory. Solar radiation was measured at the top of the mast (global radiation) and inside the stand, at a height of about $5 \mathrm{~cm}$ above ground level, with the same type of pyranometers used for estimating the extinction of solar radiation in the stand. In 1985-87, short-wave reflected radiation was also measured above each plot.

During the growing periods of $1982-86$ the sum of global radiation was rather stable from year to year (Fig. 3.2). The highest values were registered in 1983, the lowest in 1987.

\subsection{Air and soil temperature}

Dry-air and wet-bulb temperatures were measured with Pt-100 sensors; the ventilation 
Table 3.4. Mean wind speed $\left(\mathrm{m} \mathrm{s}^{-1}\right)$ at Jokioinen Observatory in May-October.

\begin{tabular}{lcccccc}
\hline & $\begin{array}{c}\text { Mean } \\
1957-1980\end{array}$ & 1983 & 1984 & 1985 & 1986 & 1987 \\
\hline May & 3.9 & 3.2 & 3.4 & 3.6 & 4.3 & 4.4 \\
June & 3.8 & 3.4 & 3.4 & 3.4 & 3.9 & 4.1 \\
July & 3.4 & 3.5 & 2.9 & 3.4 & 3.5 & 3.4 \\
August & 3.3 & 3.4 & 2.7 & 3.6 & 3.9 & 3.7 \\
September & 3.8 & 4.5 & 3.8 & 4.3 & 4.5 & 4.7 \\
October & 4.0 & 4.4 & & & 3.8 & \\
\hline
\end{tabular}

Table 3.5. Potential evapotranspiration (PET, mm) at Jokioinen Observatory in May-October.

\begin{tabular}{|c|c|c|c|c|c|c|}
\hline & $\begin{array}{c}\text { Mean } \\
1929-1986\end{array}$ & 1983 & 1984 & 1985 & 1986 & 1987 \\
\hline May & $\begin{array}{r}59 \\
+/-8\end{array}$ & 56 & 74 & 58 & 63 & 47 \\
\hline June & $\begin{array}{r}107 \\
+/-18\end{array}$ & 94 & 94 & 92 & 139 & 73 \\
\hline July & $\begin{array}{r}113 \\
+/-24\end{array}$ & 114 & 76 & 104 & 120 & 111 \\
\hline August & $\begin{array}{r}90 \\
+/-23\end{array}$ & 108 & 80 & 80 & 70 & 62 \\
\hline September & $\begin{array}{r}41 \\
+1-7\end{array}$ & 43 & 27 & 45 & 36 & 30 \\
\hline October & $\begin{array}{r}20 \\
+/-5 \\
\end{array}$ & 22 & 18 & 32 & 21 & 25 \\
\hline May-October & 430 & 437 & 369 & 411 & 449 & 348 \\
\hline
\end{tabular}

Table 3.6. Monthly precipitation ( $\mathrm{mm}$ ) at Jokioinen Observatory in April-October.

\begin{tabular}{|c|c|c|c|c|c|c|}
\hline & $\begin{array}{c}\text { Mean } \\
1957-1983\end{array}$ & 1983 & 1984 & 1985 & 1986 & 1987 \\
\hline April & 32 & 22 & 18 & 32 & 38 & 5 \\
\hline May & 40 & 44 & 66 & 43 & 52 & 38 \\
\hline June & 48 & 84 & 113 & 41 & 11 & 81 \\
\hline July & 77 & 41 & 91 & 55 & 65 & 68 \\
\hline August & 79 & 58 & 69 & 119 & 110 & 83 \\
\hline September & 66 & 86 & 77 & 51 & 102 & 120 \\
\hline October & 68 & 62 & 99 & 36 & 74 & 43 \\
\hline May-October & 378 & 375 & 515 & 345 & 414 & 438 \\
\hline
\end{tabular}

of the psychrometcrs was centralized, and was some $3 \mathrm{~m} \mathrm{~s}$ '. Soil temperature was measured with $\mathrm{Pt}-500$ sensors.

According to the effective temperature sum in degree days (ETS), with a threshold temperature of $5.0^{\circ} \mathrm{C}$, the beginning of the growing seasons were warmer than average in 1983,
1984 and 1986, but in 1985 and 1987 they were cooler, and temperatures also remained cool throughout most of these two seasons. Fairly high ETS values were observed in 1984, in June and July 1986 and in July 1987 (Fig. 3.3). Soil temperatures in May 1985 and May 1987 were $2-3^{\circ} \mathrm{C}$ below average (Table 3.3). 


\subsection{Air humidity}

Air humidity was measured psychrometrically at the mast by using dry-air temperatures. Water vapour pressure and relative humidity were calculated as follows. Saturation water vapour pressure $\left(\mathrm{e}_{\mathrm{s}}, \mathrm{hPa}\right)$ was calculated (MORTON 1975):

(3.1) $\mathrm{e}_{\mathrm{s}}=6.11 \times \exp \left(17.27 \times \mathrm{t}_{\mathrm{a}} /\left(\mathrm{t}_{\mathrm{a}}+237.3\right)\right)$

where $\mathrm{t}_{\mathrm{a}}=$ dry-air temperature $\left({ }^{\circ} \mathrm{C}\right)$.

Water vapour pressure (e) was calculated:

$$
e=e_{s w}-0.67\left(t_{a}-t_{w}\right)
$$

where $\mathrm{e}_{\mathrm{sw}}=$ saturation water vapour pressure at wet-bulb temperature $\left(\mathrm{t}_{\mathrm{w}}\right)$.

Values for relative humidity (r) were calculated using the following formula:

(3.3) $r=e / e_{s a}$

where $\mathrm{e}_{\mathrm{sa}}=$ saturation water vapour pressure at dry-air temperature $\mathrm{t}_{\mathrm{a}}$.

The air humidity in crops was measured using Humicap HM21 sensors constructed by Vaisala Oy.

\subsection{Wind speed and wind direction}

Wind speed was measured at four levels of the mast, using WAA15 sensors made by Vaisala. The top of the mast had a crossarm assembly to support an anemometer WAA15 and a wind vane WAV15.

\subsection{Potential evapotranspiration}

By using a modified version of IvanOv's equation (ANSALEhto et al. 1985), a long series of potential evapotranspiration (PET) values at Jokioinen (1929-87) was calculated for comparison. Modification was made in order to obtain the best fit for comparisons with the PET values determined with the Penman equation (Penman 1956).

For the whole growing season, the cumulative sum of the daily PET values was lower than average in 1984-1987. The values for 1983 were on the average level. In 1984 and
1985 there were, however, periods when the PET sum was higher than average (Fig. 3.4).

MAKKINK (1957) proposed the following equation for estimating potential evapotranspiration $\left(\mathrm{E}^{*}\right)$ from grass:

$$
E^{*}=0.61 \frac{D}{D+Y_{p}} \frac{S_{i}}{L}-0.12 \mathrm{~mm} / \text { day }
$$

where $\mathrm{D}=$ the slope of the curve of the saturation vapour pressure vs the temperature, $\mathrm{Y}_{\mathrm{p}}=$ the psychrometric constant $(0.67$ $\mathrm{hPa} / \mathrm{K}), \mathrm{S}_{\mathrm{i}}=$ global radiation and $\mathrm{L}=$ the latent heat of vaporization of water.

Aslyng and Hansen (1982) used a simplified version for the calculation of $\mathrm{E}^{*}$ :

$$
E^{*}=0.7 \frac{D}{D+Y_{p}} \frac{S_{i}}{L}
$$

We have calculated D using the formula of Morton (1975) (equation 3.1) and L using that of Hankimo (1964):

(3.6) $\mathrm{L}=2494-2.29 \times \mathrm{t}_{\mathrm{a}}$

where $\mathrm{t}_{\mathrm{a}}=$ the dry-air temperature at a height of $2 \mathrm{~m}$.

In the EVAPO submodel of WATCROS the following formula, which is the simple average of equations $3.1,3.5$ and 3.6 , has been found to be satisfactory:

(3.7) $\quad \mathrm{E}^{*}=0.606\left(0.399+0.0139 \mathrm{t}_{\mathrm{a}}\right) \mathrm{S}_{\mathrm{i}} / 2.47$.

For the WATCROS model E* was calculated with the modified version of PENMAN (1956), too (ASLYNG 1976)

$$
E^{*}=\frac{D\left(R_{n}-G_{g}\right)}{L\left(D+Y_{p}\right)}+\frac{Y f(v)\left(e_{s}-e_{a}\right)}{D+Y_{p}}
$$

where $R_{n}=$ the net radiation above grass, $\mathrm{G}_{\mathrm{g}}=$ ground heat flux and $\mathrm{f}(\mathrm{v})=$ the function of wind.

(3.9) $f(v)=0.263(0.5+0.54 v)$

where $\mathrm{v}=$ the mean wind speed, $\mathrm{m} \mathrm{s}^{-1}$.

Daily net radiation values were given by the nearby Meteorological Observatory. The ground heat flux values were estimated in oneweek intervals during the growth period in 
1983 - 85, using measurements by Kulmala (1970):

(3.10) $\mathrm{G}_{\mathrm{g}}=-5.5-7.959 \mathrm{dt}_{\mathrm{s}}$

where $\mathrm{dt}_{\mathrm{s}}=\mathrm{t}_{\mathrm{s}, 2}-\mathrm{t}_{\mathrm{s}, 1}$ and $\mathrm{t}_{\mathrm{s}, \mathrm{i}}=$ the mean soil temperatures in soil layers $-10 \ldots-100 \mathrm{~cm}$.

In the last two study years, $1986-87, \mathrm{G}_{\mathrm{g}}$ was calculated as earlier, but the daily values were computed according to the distribution of net radiation.

\subsection{Precipitation}

Precipitation was measured both manually and automatically. Manually observations were made using a Finnish standard gauge, Tretrakov, at one point on the field. Precipitation was recorded automatically on both the non-irrigated and the irrigated plots, using a tipping bucket rain gauge with a resolution of $0.1 \mathrm{~mm}$.

\subsection{Precipitation deficit}

Precipitation deficit $\left(D_{p}\right)$ was calculated as follows:

$$
\text { (3.11) } \mathrm{D}_{\mathrm{p}}=\mathrm{E}^{*}-\mathrm{P}
$$

where $E^{*}=$ the potential evapotranspiration (PET) and $\mathrm{P}=$ precipitation.

In 1983-1987 the precipitation deficit during the growing season was less than average; 1984 in particular was very wet. Only in 1986 was there a period, in June-August, when the precipitation deficit was greater than average (Fig. 3.5).

\section{The biological programme}

The Nordic research programme (1982-85) wanted to include plant species common to all participating countries. In Finland the Pomo cultivar was used for the barley tests, and Tarmo was the timothy variety used in 1982 -87. The turnip rape cultivar used as the test plant was Span in 1982-86 and Kova in 1987. Of these plants only rape (Span) was cultivated in Denmark and Norway, too.

Plots of barley and turnip rape were established in the standard way each year. Timothy stands were clear seeded in 1982 and established with a cover crop barley in 1984. Because of the clear seeding and winter damages (Table 4.1), the growing seasons of 1982 and 1984 were discarded in timothy modelling. The barley plant stands were been quite dense in all years exept 1982. Turnip rape stands sprouted poorly throughout the study ( $\mathrm{Ta}$ ble 4.2).

Barley and turnip rape were fertilized with NPK (16-7-13) and timothy with NPK (20-4-8) fertilizers. The amounts of nutrients as $\mathrm{kg}$ per hectare for barley and turnip rape were $80-100 \mathrm{~kg}$ nitrogen $(\mathrm{N}), 35-40 \mathrm{~kg}$ phosphorous $(\mathrm{P})$ and $40-65 \mathrm{~kg}$ potassium $(\mathrm{K})$. For grass, the amounts after the year of establish-

Table 4.1. Wintering and Total available Carbohydrates (TAC) in root DM of timothy.

\begin{tabular}{|c|c|c|c|c|c|}
\hline \multirow[t]{2}{*}{ Year } & \multirow[t]{2}{*}{ Plot } & \multicolumn{2}{|c|}{ TAC $\%$} & \multicolumn{2}{|c|}{ Stand Density $\%$} \\
\hline & & Spring & Autumn & Spring & Autumn \\
\hline \multirow[t]{2}{*}{1983} & $\mathrm{Cl}$ & 10.3 & 26.8 & 89 & 79 \\
\hline & $\mathrm{C} 2$ & 9.8 & 26.8 & 98 & 75 \\
\hline \multirow[t]{2}{*}{1984} & $\mathrm{Cl} / \mathrm{Bl}$ & 9.1 & 18.6 & 65 & $>90$ \\
\hline & $\mathrm{C} 2 / \mathrm{B} 2$ & 7.2 & 18.9 & 25 & $>90$ \\
\hline \multirow[t]{2}{*}{1985} & B1 & 7.3 & 17.1 & 85 & 85 \\
\hline & B2 & 7.6 & 18.2 & 81 & 80 \\
\hline \multirow[t]{2}{*}{1986} & B1 & 6.8 & 6.8 & 72 & 68 \\
\hline & B2 & 3.5 & 7.8 & 73 & 76 \\
\hline \multirow[t]{2}{*}{1987} & B1 & 6.1 & 8.2 & 63 & 75 \\
\hline & B2 & 4.1 & 10.0 & 70 & 75 \\
\hline
\end{tabular}


Table 4.2. Shooting of barley and turnip rape in 1982-87 per $\mathrm{m}^{-2}$.

\begin{tabular}{|c|c|c|}
\hline Year & Barley & Turnip rape \\
\hline 1982 & $\begin{array}{l}333 \\
334\end{array}$ & $\begin{array}{l}108 \\
179\end{array}$ \\
\hline 1983 & $\begin{array}{l}520 \\
427\end{array}$ & $\begin{array}{l}288 \\
256\end{array}$ \\
\hline 1984 & $\begin{array}{l}587 \\
501\end{array}$ & $\begin{array}{l}245 \\
269\end{array}$ \\
\hline 1985 & $\begin{array}{l}518 \\
500\end{array}$ & $\begin{array}{l}282 \\
320\end{array}$ \\
\hline 1986 & $\begin{array}{l}437 \\
507\end{array}$ & $\begin{array}{l}270 \\
287\end{array}$ \\
\hline 1987 & $\begin{array}{l}539 \\
512 \\
\end{array}$ & $\begin{array}{l}410 \\
389 \\
\end{array}$ \\
\hline Mean $1983-87$ & 505 & 300 \\
\hline
\end{tabular}

ment were: first cut $100-110 \mathrm{~kg} \mathrm{~N}, 20 \mathrm{~kg} \mathrm{P}$ and $40-60 \mathrm{~kg} \mathrm{~K}$; second cut $80 \mathrm{~kg} \mathrm{~N}, 20-35$ $\mathrm{kg} \mathrm{P}$ and $40-65 \mathrm{~kg} \mathrm{~K}$; third cut $40-60 \mathrm{~kg}$ $\mathrm{N}, 20-30 \mathrm{~kg} \mathrm{P}$ and $30-50 \mathrm{~kg} \mathrm{~K}$. In 1982 and 1984 timothy was established by using $500 \mathrm{~kg}$ per hectare of NPK (16-7-13) fertilizer.

Plant protection was considered important for avoiding the influence of weeds, plant diseases and pests on yield and crop green area. The chemicals used and the timing of their sprayings are shown in Table 4.3. In 1984, turnip rape was sowed twice, but insect pests also caused some damage to the second plant stand despite protection.

During the growing season, the plants were monitored according to the programme of biological measurements. The central measurements were made weekly, except for some parameters which were monitored infrequently during the growth period or only at the time of harvest (Table 4.4).

\section{Plant growth and development}

\subsection{Crop surface}

Instead of the leaf area index (LAI), AsLynG and HANSEN (1982) adopted the total crop area index (CAI), the green area index
(GAI) and the yellow area index (YAI). These indices are the accumulated areas of leaves, stalks, stems and ears divided by the corresponding land surface. The total crop area influences the interception of radiation and precipitation, and the total green area corresponds to photosynthesis.

The growth period here is defined as the period from emerging to ripening for barley and turnip rape. In the case of timothy, growth is assumed to start at the beginning of the thermal growth period $\left(\geq 5^{\circ} \mathrm{C}\right)$ and to end at the time of the last harvest.

The green and yellow crop area of studied plant species was measured with an automatic leaf area meter (HAYASHI DENKOD AAM-7). The yellow crop area was measured during the years of 1985-87). In the best years, timothy grass reached a GAI value over 15 , barley near 10 and turnip rape only 8 (see chapter 8).

\subsection{Root growth}

In $1982-84$ only the amount of main roots of the tillage layer $(0-20 \mathrm{~cm})$ was measured at the time of cutting in the autumn. From the year 1985 on, root growth was monitored more carefully in order to learn how fast the

Table 4.3. Plant protection schedule in the experimental field.

\begin{tabular}{|c|c|c|c|}
\hline Year & Turnip rape & Barley & Timothy \\
\hline 1982 & $\begin{array}{l}\text { 23/6 Decis } \\
\text { 2/7 Decis } \\
\text { 9/7 Sumicidin }\end{array}$ & & $\begin{aligned} 6 / 7 & \text { Dipro } \\
23 / 8 & \text { PCNB } \\
28 / 12 & \text { Avicol }\end{aligned}$ \\
\hline 1983 & $\begin{array}{l}\text { 13/6 Decis } \\
\text { 20/6 Decis }\end{array}$ & 9/6 Dipro & $25 / 5$ Actril $S$ \\
\hline 1984 & $\begin{array}{r}\text { 18/6 Decis } \\
\text { 4/7 Decis }\end{array}$ & & 18/6 Actril S \\
\hline 1985 & $\begin{array}{l}\text { 19/6 Butisan } \\
\text { 19/6 Decis } \\
\text { 24/6 Decis } \\
\text { 27/6 Decis } \\
\text { 4/7 Decis }\end{array}$ & $\begin{array}{l}\text { 19/6 Dipro } \\
\text { 19/6 Roxion }\end{array}$ & 16/5 Actril S \\
\hline 1986 & $\begin{array}{l}\text { 13/6 Roxion } \\
\text { 18/6 Roxion }\end{array}$ & & \\
\hline 1987 & $\begin{aligned} 26 / 6 & \text { Decis } \\
3 / 7 & \text { Decis }\end{aligned}$ & 23/6 Herbalon & \\
\hline
\end{tabular}


Table 4.4. Biological programme for the experimental field.

\begin{tabular}{|c|c|c|c|}
\hline Management & Barley & Turnip rape & Timothy \\
\hline $\begin{array}{l}\text { Seeding rate } \\
(\mathrm{kg} / \mathrm{ha}) \text { : }\end{array}$ & $\begin{array}{l}180 \\
\left(500 / \mathrm{m}^{2}\right)\end{array}$ & $\begin{array}{l}8 \\
1987,12\end{array}$ & 25 \\
\hline Seeding depth $(\mathrm{cm})$ : & $3-5$ & 3 & 1.5 \\
\hline Emergence date: & \multicolumn{3}{|c|}{ when $50 \%$ sprouting } \\
\hline CAI (starting at $10 \mathrm{~cm}$ height, whole crop): & \multicolumn{3}{|c|}{$6 \times 30 \mathrm{~cm}$ at raw weekly } \\
\hline Fresh weight (starting one week after CAI): & \multicolumn{3}{|c|}{$3 \times 1.5 \mathrm{~m}^{2}$ weekly } \\
\hline Cutting height $(\mathrm{cm})$ : & \multicolumn{3}{|c|}{5} \\
\hline DM determinations: & \multicolumn{3}{|c|}{$2 \times 200 \mathrm{~g} 100^{\circ} \mathrm{C}$} \\
\hline Height measurements: & \multicolumn{3}{|c|}{5 points $/ 1.5 \mathrm{~m}^{2}$} \\
\hline Heading date: & \multicolumn{3}{|c|}{ at the time of $1 \mathrm{st}$ ear $/ \mathrm{m}^{2}$} \\
\hline Maturity date: & \multicolumn{3}{|c|}{ determined } \\
\hline Root sampling (at end harvest): & \multicolumn{3}{|c|}{$2-3 \times 50 \mathrm{~cm}$ at raw $(15 \mathrm{~cm}$ depth) } \\
\hline Number of plants (at end harvest): & \multicolumn{3}{|c|}{$3-6 \times 1 \mathrm{~m}$ at raw } \\
\hline Number of ears/panicles (at end harvest): & \multicolumn{3}{|c|}{$3-6 \times 1 \mathrm{~m}$ at raw } \\
\hline Straw yield DM (cutting $5 \mathrm{~cm}$ ): & \multicolumn{3}{|c|}{$4-6 \times 20 \mathrm{~m}^{2}$ (fall) } \\
\hline $\begin{array}{l}\text { Grain yield (barley } 15 \% \text { and turnip rape } \\
9 \% \text { moisture content): }\end{array}$ & \multicolumn{3}{|c|}{$4-6 \times 20 \mathrm{~m}^{2}$ (fall) } \\
\hline 1000 seed weight & \multicolumn{3}{|c|}{$3 \times 100$ seeds } \\
\hline
\end{tabular}

roots penetrate to the clay soil and the quantity with which they remain in the field. In 1985 root density in the soil $\left(\mathrm{cm} / \mathrm{cm}^{3}\right)$ was measured by NEwMAN's (1966) method for estimating the total length of root sampling (Table 5.1). According to MADSEN (1978), the effective root depth comprises at least $0.1 \mathrm{~cm}$ root per $\mathrm{cm}^{3}$ soil.

In 1986 and 1987, root depth growth was measured from emergence to the time when a root depth of $60 \mathrm{~cm}$ was attained. According to these results the average root penetration speed was $1.3 \mathrm{~cm}$ per day for barley, 1.2 $\mathrm{cm}$ per day for turnip rape and $0.7 \mathrm{~cm}$ per day for timothy. Root depth growth was not the same for the whole growth period (Table 5.2). According to JАKOBSI:N's (1976) formula of root growth, with a threshold soil temperature of $4^{\circ} \mathrm{C}$, the soil temperature of the root penetration zone did not restrict the root growth of barley or turnip rape during 198387. At the time of sowing the soil temperature of the tillage layer was uniformly $+10^{\circ} \mathrm{C}$ or more. According to this formula, soil temperature restricted the root growth of timo- thy about 1 to 2 weeks after the onset of the growth period.

The studies showed that the maximum effective root depth $\left(d_{r}\right)$ remained $\leq 75 \mathrm{~cm}$ for all three plant species. SALONEn (1949), study-

Table 5.1. Root length, $\mathrm{cm}$ in $\mathrm{cm}^{3}$ soil in 1985.

\begin{tabular}{|c|c|c|c|}
\hline \multirow{2}{*}{$\begin{array}{l}\text { Depth } \\
\mathrm{cm}\end{array}$} & \multicolumn{3}{|c|}{ Date } \\
\hline & $28 / 5$ & $11 / 6$ & $8 / 7$ \\
\hline & & Timothy & \\
\hline $00-10$ & 9.0 & & \\
\hline $10-20$ & 0.7 & & \\
\hline $20-30$ & 0.3 & 0.4 & 1.8 \\
\hline $30-40$ & & 0.2 & 0.9 \\
\hline $40-50$ & & 0.0 & 0.5 \\
\hline \multirow[t]{2}{*}{$50-60$} & & & 0.2 \\
\hline & & Barley & \\
\hline $00-10$ & & 1.7 & \\
\hline $10-20$ & & 0.7 & 2.9 \\
\hline $20-30$ & & & 1.2 \\
\hline $30-40$ & & & 1.2 \\
\hline \multirow[t]{2}{*}{$40-50$} & & & 0.8 \\
\hline & & Turnip rape & \\
\hline $10-20$ & & & 1.6 \\
\hline $20-30$ & & & 0.9 \\
\hline $30-40$ & & & 0.5 \\
\hline
\end{tabular}


Table 5.2. Root depth growth.

\begin{tabular}{ccc}
\hline Year Date (Days) & $\begin{array}{c}\text { Soil } \\
\text { depth } \\
\mathrm{cm}\end{array}$ & $\begin{array}{c}\text { Depth } \\
\text { growth } \\
\mathrm{cm} / \text { day }\end{array}$ \\
\hline
\end{tabular}

Barley

\begin{tabular}{lrlrl}
1986 & $3 / 6-23 / 6$ & $(21)$ & $0-25$ & 1.2 \\
& $24 / 6-14 / 7$ & $(21)$ & $25-60$ & 1.7 \\
\hline Avg. & $3 / 6-14 / 7$ & $(42)$ & $0-60$ & 1.4 \\
1987 & $5 / 6-29 / 6$ & $(25)$ & $0-25$ & 1.0 \\
& $30 / 6-28 / 7$ & $(29)$ & $25-64$ & 1.3 \\
\hline Avg. & $5 / 6-28 / 7$ & $(54)$ & $0-64$ & 1.2
\end{tabular}

Turnip rape

\begin{tabular}{rrrrr}
1986 & $3 / 6-23 / 6$ & $(21)$ & $0-10$ & 0.5 \\
& $24 / 6-21 / 7$ & $(28)$ & $10-60$ & 1.8 \\
\hline Avg. & $3 / 6-21 / 7$ & $(49)$ & $0-60$ & 1.2 \\
1987 & $8 / 6-29 / 6$ & $(22)$ & $0-19$ & 0.9 \\
& $30 / 6-28 / 7$ & $(29)$ & $19-60$ & 1.4 \\
\hline Avg. & $8 / 6-28 / 7$ & $(51)$ & $0-60$ & 1.2
\end{tabular}

\section{Timothy}

\begin{tabular}{lllrl}
1986 & $25 / 4-19 / 5$ & $(24)$ & $0-20$ & 0.8 \\
& $20 / 5-16 / 6$ & $(28)$ & $20-35$ & 0.5 \\
& $17 / 6-14 / 7$ & $(29)$ & $35-60$ & 0.9 \\
\hline Avg. & $25 / 4-14 / 7$ & $(81)$ & $0-60$ & 0.7 \\
1987 & $23 / 4-18 / 5$ & $(25)$ & $0-6$ & 0.2 \\
& $19 / 5-16 / 6$ & $(29)$ & $6-51$ & 1.6 \\
& $17 / 6-20 / 7$ & $(35)$ & $51-61$ & 0.3 \\
\hline Avg. & $23 / 4-20 / 7$ & $(89)$ & $0-61$ & 0.7 \\
\hline
\end{tabular}

ing barley and timothy root growth in different soil types, showed a maximum root depth of $35-85 \mathrm{~cm}$ for barley and $40-70 \mathrm{~cm}$ for timothy in clay soils. In Denmark the average effective root depth in clay soil has been $100 \mathrm{~cm}$ containing $170 \mathrm{~mm}$ water as a root zone capacity.

In 1983-1985 the amount of main roots was only $400-500 \mathrm{~kg}$ for barley and $250-400$ $\mathrm{kg}$ of dry matter (DM) per hectare for turnip rape. Careful washing of soil samples to a depth of $60 \mathrm{~cm}$ in 1986 introduced root DM yields of barley $1000-1500 \mathrm{~kg}$ and $500-550$ $\mathrm{kg}$ per hectare for turnip rape. Timothy had a $2-4$ ton root DM mass per hectare, but that sum also contained old, dead roots (Table 5.3).

\subsection{Dry matter production}

Crop growth was measured weekly throughout the study period. Cuttings were measured weekly from a plant height of about $20 \mathrm{~cm}$, the measurements continuing until the end harvest. Daily above ground $(>5 \mathrm{~cm})$ dry matter production per hectare for barley after emergence was $50-90 \mathrm{~kg}$ of DM per day

Table 5.3. Total amount of roots $(\mathrm{kg} \mathrm{DM} / \mathrm{ha})$ in 1986.

\begin{tabular}{|c|c|c|c|c|c|c|c|}
\hline \multirow[t]{2}{*}{ Plot } & \multicolumn{7}{|c|}{ Soil Depth $(\mathrm{cm})$} \\
\hline & $00-10$ & $10-20$ & $20-30$ & $30-40$ & $40-50$ & $50-60$ & $00-60$ \\
\hline \multicolumn{8}{|c|}{ Barley } \\
\hline $\mathrm{Cl}$ & 991 & 265 & 158 & 44 & 20 & 43 & 1521 \\
\hline $\mathrm{C} 2$ & 632 & 139 & 110 & 71 & 63 & 18 & 1033 \\
\hline Avg. & 812 & 202 & 134 & 58 & 42 & 30 & 1277 \\
\hline \multicolumn{8}{|c|}{ Turnip rape } \\
\hline Al & 280 & 102 & 95 & 56 & 22 & - & 555 \\
\hline A 2 & 305 & 54 & 82 & 56 & 28 & - & 525 \\
\hline Avg. & 292 & 78 & 88 & 56 & 25 & - & 540 \\
\hline \multicolumn{8}{|c|}{ Timothy } \\
\hline B1 & 2478 & 170 & 110 & 37 & 22 & - & 2817 \\
\hline B2 & 3377 & 195 & 120 & 32 & 24 & 9 & 3757 \\
\hline Avg. & 2928 & 182 & 115 & 34 & 23 & 4 & 3287 \\
\hline
\end{tabular}


and increased during the next four to six weeks to a maximum value of $200-300 \mathrm{~kg}$ of DM per day. At the very early phase of the development, turnip rape growth was very slow, but the pace of growth increased quickly after the sprouting period to a level of $100-150$ $\mathrm{kg}$ of DM per day. The maximum values were $150-250 \mathrm{~kg}$ of DM per day. The DM growth of timothy varied enourmously from one year to another and also between cuts. During spring, daily grass growth was $50-100 \mathrm{~kg}$ of $\mathrm{DM}$, and later reached the maximum value of $200-250 \mathrm{~kg}$ of DM per day. Summer grass growth varied between 30 and $180 \mathrm{~kg}$ of DM per day. The autumn growth of timothy ranged from 10 to $100 \mathrm{~kg}$ of DM per day. (see chapter 8.)

\section{Results of the end harvestings}

\subsection{Barley and turnip rape}

Table 6.1 shows the results of dry matter production at harvests, divided into grain DM yield and total production above ground level $(>5 \mathrm{~cm})$. End harvests were done with an experimental harvester on four to six subplots, each $20 \mathrm{~m}^{2}$ in size. Straw and grain were separated, but it was impossible to keep the cutting height constant at a stubble height level of $5 \mathrm{~cm}$. When results of end harvests were compared to those of the last periodic cuttings, the existing error was estimated to be about $10-15 \%$ of the actual total dry matter yield.

Plant height and harvest analyses are presented in Tables 6.2 and 6.3. Harvest index values of barley and turnip rape were calculated as the dry matter yield of grain (seed) at the end harvest per the maximum measured ( $>5 \mathrm{~cm}$ ) crop dry matter yield of the growth period. The shoot height growth of barley ended at the time when the maximum GAI values were reached. In the case of turnip rape, height development was related to the time of blooming.

The best growing conditions for DM production of the studied crops occurred in 1983, which was warm and dry. In 1985 and 1986, irrigation had a positive effect on plant height development, but the yields were greater only in 1986. 1987 was a cloudy, cold and rainy year and was the least favourable year for plant production since 1962 .

\subsection{Timothy}

Timothy plots were established in the spring of 1982 and of 1984. These years were not included in crop growth simulation (Table 6.4).

Table 6.1. Growth period, dry matter production above ground level ( $>5 \mathrm{~cm}$ ) and grain yield of barley and turnip rape at end harvest $(\mathrm{kg} \mathrm{DM} / \mathrm{ha})$.

\begin{tabular}{|c|c|c|c|c|c|c|c|c|c|}
\hline \multirow[t]{2}{*}{ Year } & \multirow[t]{2}{*}{ Plot } & \multicolumn{4}{|c|}{ Dates of } & \multicolumn{2}{|c|}{ Non-irrigated } & \multicolumn{2}{|c|}{ Irrigated } \\
\hline & & Sowing & Emerging & Ripening & Harvest & Grain & Total & Grain & Total \\
\hline \multicolumn{10}{|c|}{ Barley } \\
\hline 1982 & B & $27 / 5$ & $5 / 6$ & $23 / 8$ & $7 / 9$ & 4023 & 6525 & 3224 & 5896 \\
\hline 1983 & A & $10 / 5$ & $20 / 5$ & $8 / 8$ & $11 / 8$ & 4408 & 8580 & 4167 & 8276 \\
\hline 1984 & B & $15 / 5$ & $21 / 5$ & $10 / 8$ & $15 / 8$ & 3483 & 7031 & 3591 & 7571 \\
\hline 1985 & A & $24 / 5$ & $2 / 6$ & $23 / 8$ & $26 / 8$ & 3891 & 6617 & 3283 & 6824 \\
\hline 1986 & $\mathrm{C}$ & $27 / 5$ & $3 / 6$ & $23 / 8$ & $28 / 8$ & 3630 & 6122 & 4604 & 7920 \\
\hline 1987 & A & $26 / 5$ & $5 / 6$ & $8 / 9$ & $17 / 9$ & 2994 & 6294 & 3012 & 6208 \\
\hline \multicolumn{10}{|c|}{ Turnip rape } \\
\hline 1982 & A & $27 / 5$ & $7 / 6$ & $13 / 9$ & $16 / 9$ & 1702 & 3832 & 1815 & 4326 \\
\hline 1983 & B & $10 / 5$ & $20 / 5$ & $18 / 8$ & $25 / 8$ & 1482 & 5388 & 1647 & 5636 \\
\hline 1984 & A & $31 / 5$ & $4 / 6$ & $3 / 9$ & $10 / 9$ & 650 & 1735 & 877 & 2748 \\
\hline 1985 & $\mathrm{C}$ & $24 / 5$ & $3 / 6$ & $9 / 9$ & $12 / 9$ & 1726 & 4833 & 1560 & 4603 \\
\hline 1986 & A & $27 / 5$ & $3 / 6$ & $13 / 9$ & $19 / 9$ & 1323 & 3835 & 1566 & 5188 \\
\hline 1987 & C & $26 / 5$ & $6 / 6$ & $23 / 9$ & $2 / 10$ & 1450 & 5330 & 1259 & 5403 \\
\hline
\end{tabular}


Table 6.2. Harvest analyses of Pomo barley in 1983-87.

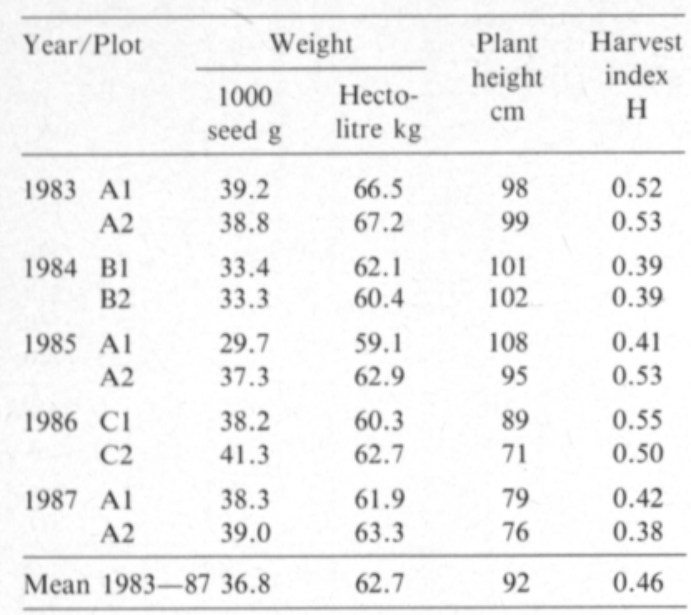

The best growing season for grass production occurred in 1983, when the total DM yield above ground was about 11 tons of DM per hectare (Table 6.5). For timothy, the growth of plant height was equal to the development of GAI.

The spring of 1985 was cold, and the yields of the first end cut were the lowest of any of the studied years. In 1985 and 1986, irrigation after the first end harvest hastened the development of crop growth. In 1987 grass development was slow and only two end cuttings were taken, but the DM yield was still about 9 tons per hectare.

\section{The model}

\subsection{Simulation of the crop area}

AsLyng and Hansen (1982) used the longterm average $\mathrm{CAI}$ and $\mathrm{GAI}$ values of the stud-
Table 6.3. Harvest analyses of Span turnip rape (KovA 1987) in 1983-87.

\begin{tabular}{llcrc}
\hline Year/Plot & $\begin{array}{c}\text { Weight } \\
1000 \\
\text { seed g }\end{array}$ & $\begin{array}{c}\text { Plant } \\
\text { height } \\
\text { cm }\end{array}$ & $\begin{array}{c}\text { Harvest } \\
\text { index } \\
\text { H }\end{array}$ \\
\hline 1983 & B1 & 2.44 & 111 & 0.25 \\
& B2 & 2.31 & 110 & 0.20 \\
1984 & A1 & 2.61 & 85 & 0.26 \\
& A2 & 2.46 & 90 & 0.18 \\
1985 & C1 & 2.83 & 127 & 0.25 \\
& C2 & 2.40 & 105 & 0.28 \\
1986 & A1 & 2.73 & 100 & 0.25 \\
& A2 & 2.60 & 78 & 0.28 \\
1987 & C1 & 2.88 & 88 & 0.22 \\
& C2 & 2.82 & 88 & 0.24 \\
\hline \multicolumn{1}{l}{ Mean } & $1983-87$ & 2.61 & 98 & 0.24 \\
\hline
\end{tabular}

ied crops when developing their simulation model. For the crops surface development of used model, it is necessary to know the date of emergence (JDAY1), the date when the GAI values reach 5 (JDAY2), the date of the developmental point when the GAI decreases below 5 (JDAY3) and the date of full maturity, when the GAI $=0$ (JDAY4). In cereals the CAI is 0 before emergence; it then rises exponentially to 5 :

$$
\begin{aligned}
& \mathrm{CAI}=\mathrm{G}_{\mathrm{m}}(\exp (2.4(\mathrm{t}-\mathrm{JDAY} 1) / \\
& (\mathrm{JDAY}-\mathrm{JDAY} 1))-1) / 10
\end{aligned}
$$

where $\mathrm{t}=$ time, JDAYs $=$ Julian days from the beginning of the year and $\mathrm{G}_{\mathrm{m}}=$ the maximum value of GAI.

In the model of maximum value of $\mathrm{GAI}$ $\left(\mathrm{G}_{\mathrm{m}}\right)$ is stated as 5 to the onset of ripening. GAI values over 5 had a minor influence on the amount of energy absorbed by the crop (AsLYNG and Hansen 1982). After the onset

\begin{tabular}{|c|c|c|c|c|c|c|c|}
\hline \multirow[t]{2}{*}{ Year/Plot } & \multicolumn{3}{|c|}{ Dates of } & \multicolumn{2}{|c|}{ DM yield } & \multicolumn{2}{|c|}{ Plant height } \\
\hline & Sowing & Emerging & Harvest & 1 & 2 & 1 & 2 \\
\hline $1982 \mathrm{C}$ & $27 / 5$ & $7 / 6$ & $6 / 9$ & 1417 & 1898 & 59 & 45 \\
\hline 1984 В & $14 / 5$ & $24 / 5$ & $5 / 9$ & 1731 & 2591 & 45 & 40 \\
\hline
\end{tabular}

Table 6.4. Dry matter production $(\mathrm{kg} \mathrm{DM} / \mathrm{ha})$ and plant height of timothy in the years of establishment.

KEY: Plot 1 =irrigated, 2 =non-irrigated 
Table 6.5. Dry matter production $(\mathrm{kg} \mathrm{DM} / \mathrm{ha})$ and plant height $(\mathrm{cm})$ of timothy in grass years.

\begin{tabular}{|c|c|c|c|c|c|c|c|c|}
\hline \multicolumn{2}{|c|}{ Year/Plot } & \multicolumn{2}{|c|}{ Dates of } & \multicolumn{2}{|c|}{ Plant height } & & \multicolumn{2}{|c|}{ DM yield } \\
\hline & & Onset & Harvest & 1 & 2 & & 1 & 2 \\
\hline \multirow[t]{4}{*}{1983} & $\mathrm{C}$ & $20 / 4$ & $16 / 6$ & 103 & 105 & & 6654 & 6893 \\
\hline & & & $2 / 8$ & 59 & 62 & & 2817 & 2777 \\
\hline & & & $9 / 9$ & 26 & 36 & & 1548 & 778 \\
\hline & & & & & & Sum & 11019 & 10448 \\
\hline \multirow[t]{4}{*}{1985} & B & $8 / 5$ & $24 / 6$ & 66 & 67 & & . 2231 & 2958 \\
\hline & & & $12 / 8$ & 83 & 95 & & 4058 & 2750 \\
\hline & & & $26 / 9$ & 33 & 25 & & 983 & 1240 \\
\hline & & & & & & Sum & 7272 & 6948 \\
\hline \multirow[t]{4}{*}{1986} & B & $25 / 4$ & $13 / 6$ & 76 & 74 & & 5118 & 4995 \\
\hline & & & $4 / 8$ & 79 & 43 & & 3211 & 1172 \\
\hline & & & $8 / 9$ & 26 & 35 & & 558 & 911 \\
\hline & & & & & & Sum & 8887 & 7078 \\
\hline \multirow[t]{3}{*}{1987} & B & $30 / 4$ & $25 / 6$ & 76 & 75 & & 4269 & 4340 \\
\hline & & & $10 / 9$ & 96 & 86 & & 4593 & 5067 \\
\hline & & & & & & Sum & 8862 & 9407 \\
\hline
\end{tabular}

KEY: Plot: 1 =irrigated, 2 =non-irrigated

of ripening, the GAI and CAI values decrease linearly to full ripening $(\mathrm{GAI}=0)$, and in cereals the CAI at harvest equals $2(\mathrm{YAI}=2)$ :

(7.2) $\quad \mathrm{GAI}=\mathrm{G}_{\mathrm{m}}-\mathrm{G}_{\mathrm{m}}(\mathrm{t}-\mathrm{JDAY} 3) /$ (JDAY4 - JDAY3)

$$
\begin{aligned}
& \mathrm{CAI}=\mathrm{G}_{\mathrm{m}}-\left(\mathrm{G}_{\mathrm{m}}-\mathrm{Y}\right)(\mathrm{t}-\mathrm{JDAY} 3) / \\
& (\mathrm{JDAY} 4-\mathrm{JDAY} 3)
\end{aligned}
$$

where $\mathrm{Y}=$ the yellow area index (YAI).

The same type of crop area model was applied for turnip rape as for barley, fit to the development of rape. The turnip rape stand did not always reach a GAI value of 5. In 1984 the maximum value of 2.5 was used for rape, because leaf area development was poor.

The simulation model of GAI for grass was developed for Italian ryegrass cut five times during the growing season (ASLYNG and HAN. SEN 1982). We used the same type of GAI model for timothy in a three cut system. Development of GAI to the value of 5 was the same as for barley; a GAI unit of 0.5 was added to describe the plant stand after cuttings:

$$
\begin{aligned}
& \mathrm{CAI}=\mathrm{G}_{\mathrm{m}}(\exp 2.4(\mathrm{t}-\mathrm{JDAY} 1) / \\
& (\mathrm{JDAY} 2-\mathrm{JDAY} 1))-1) / 10+(0.5)
\end{aligned}
$$

For the timothy simulation model of GAI, the $G_{m}$-value of 5 remains stable until harvest.

Aslyng and Hansen (1982) used the common development of GAI, which depends on the temperature sum. Our data of GAI in all plant species showed that GAI development varied yearly and was not entirely dependent on the effective temperature sum (ETS,> $5^{\circ} \mathrm{C}$ ). In our study it was more reliable to simulate the real yearly development of GAI for all three species studied (Fig. 7.1-7.3).

\subsection{Actual evapotranspiration}

Daily evapotranspiration was calculated according to the EVAPO simulation model (Aslyng and HanSEn 1982). The input parameters of this submodel are precipitation (P), irrigation (I) and potential evapotranspiration $\left(E^{*}\right)$. The daily values of maximum effective root depth $\left(\mathrm{d}_{\mathrm{r}}\right)$ and crop area index (CAI) are also needed. The soil water capacity is divided into two parts. The topsoil reservoir $\left(\mathrm{S}_{1}^{*}\right)$ is considered to occupy the upper $10 \mathrm{~cm}$ layer of the soil, and is stated contain- 

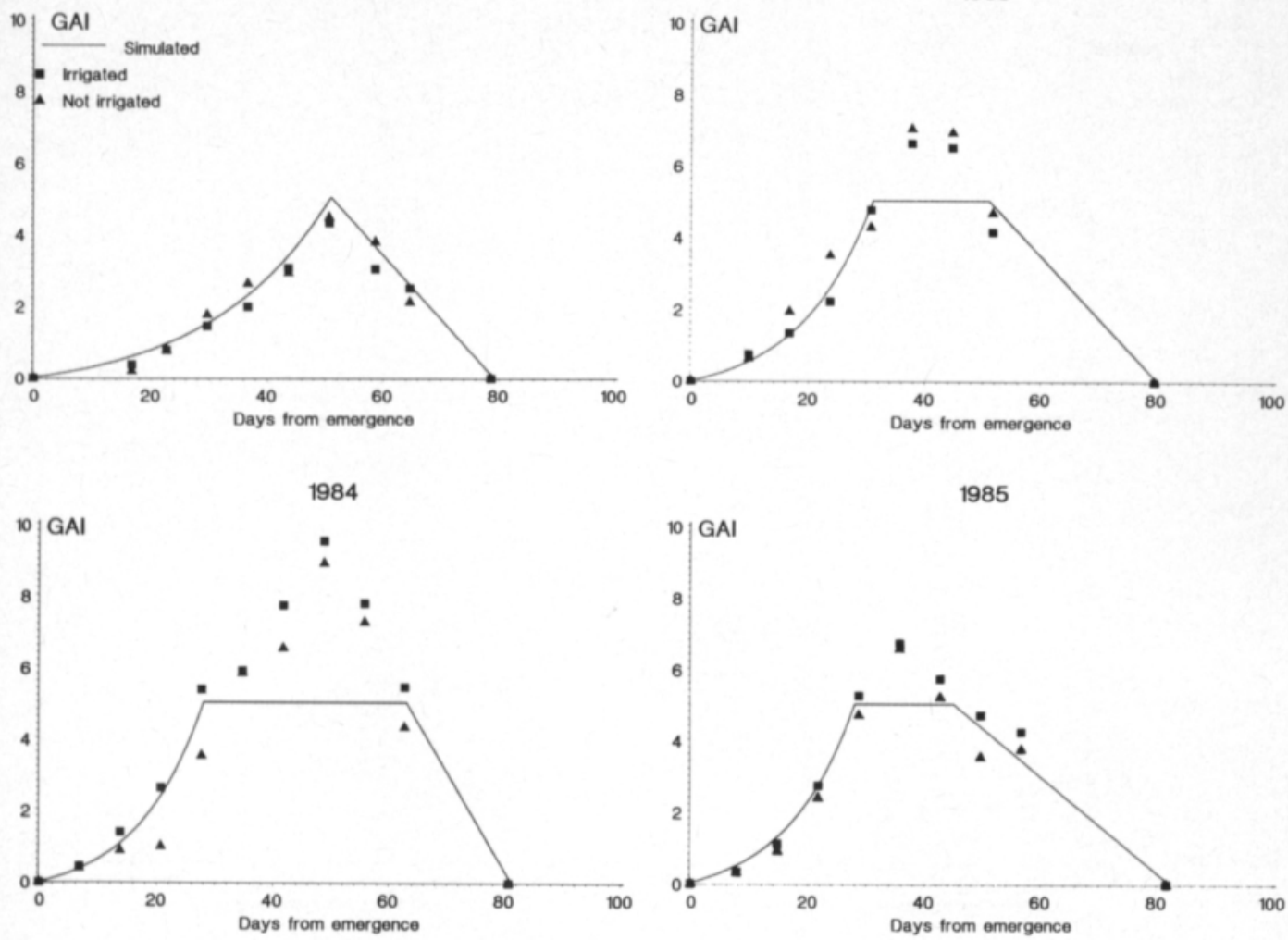

1986

1987
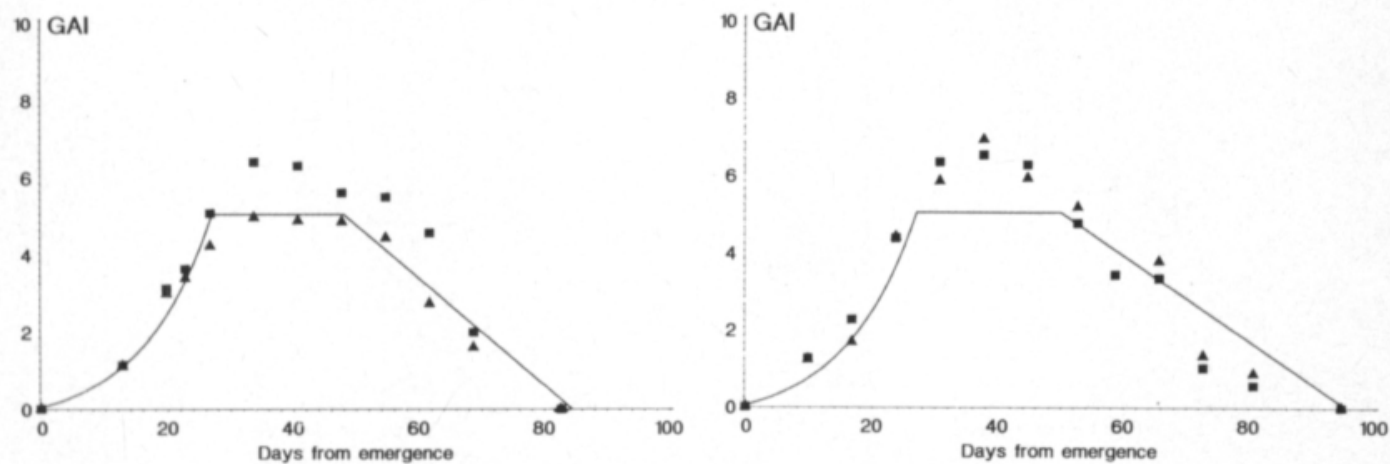

Fig. 7.1. Simulated and measured green area index (GAI) of barley in 1982-87.

ing $10 \mathrm{~mm}$ water. HEINONEN (1985) proposed that this reservoir is a "microrelief of the surface", which delays the beginning of the flow of the surface water. $\mathrm{S}_{1}^{*}$ is not independent of the root zone reservoir, which is considered to be a function of soil type and the effective root depth. $\mathrm{S}_{1}^{*}$ can be readily evaporated from the soil surface, and root zone reservoir is available to the plants in the root zone.
The priori assumption is that the actual evapotranspiration (E) can reach, but cannot exceed, the potential evapotranspiration. In the EVAPO model a break point $\left(\mathrm{E} / \mathrm{E}^{*}=1.0\right)$ is adopted, when $50 \%$ of the water is used by the plants. The pressure head at which soil water begins to limit plant growth seems to range between a pF-value 2.6 and 3 (FEDDES et al. 1978). Denmead and Shaw (1962) 


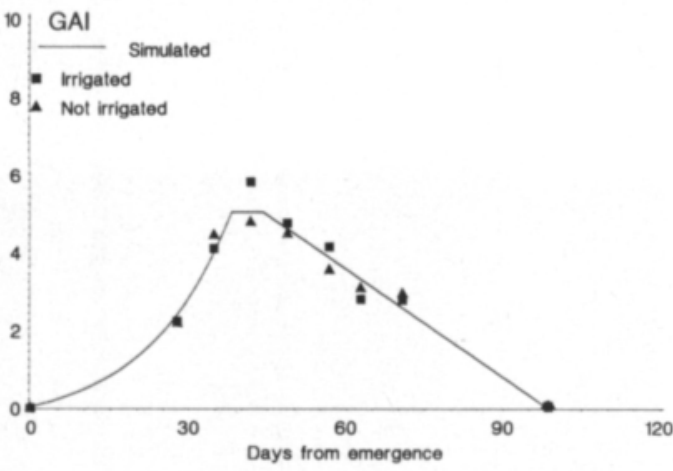

1984

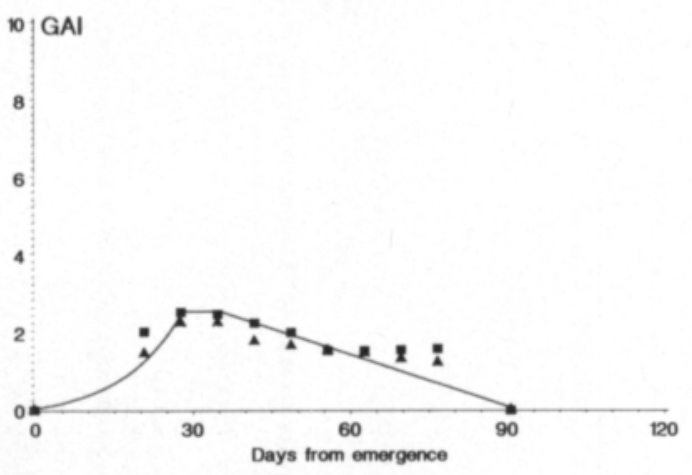

1986

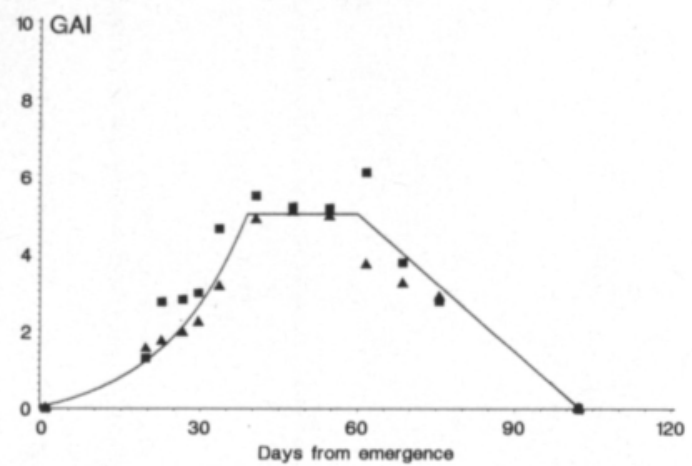

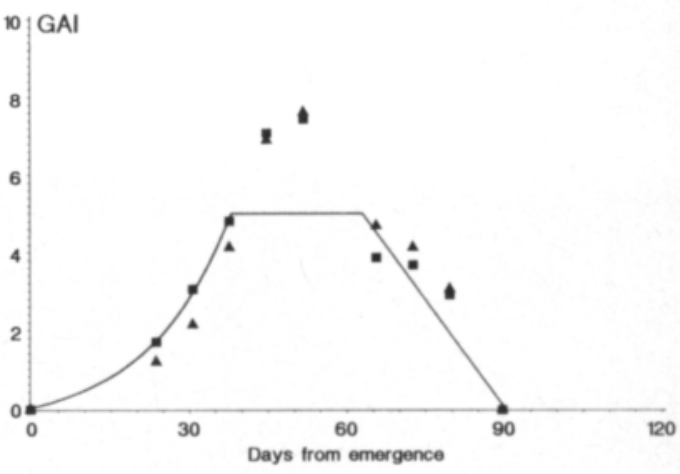

1985

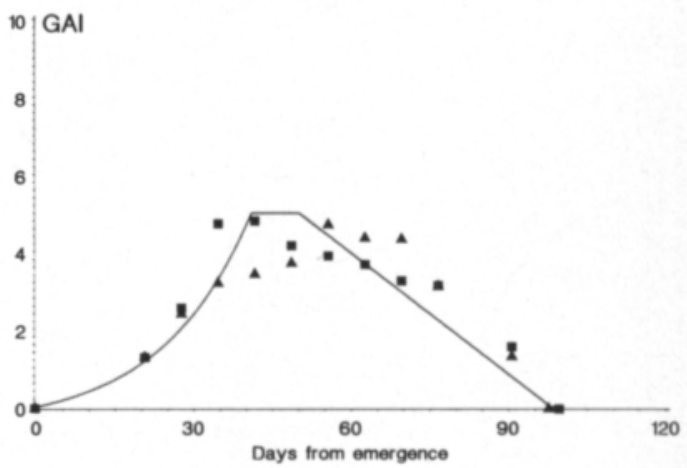

1987

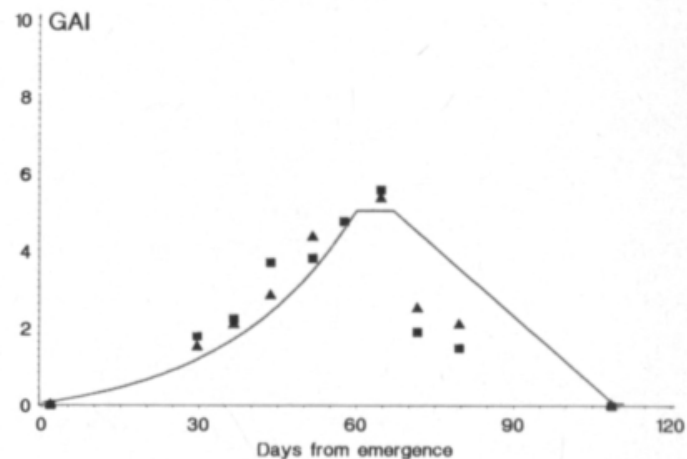

Fig. 7.2. Simulated and measured green area index (GAI) of turnip rape in 1982-87.

reported the influence of particular meteorological conditions on the relationship between actual and potential transpiration. They determined the point of soil moisture at which the wilting of the plants increased at the same rate as the increase in potential transpiration. LONG and FRENCH (1967) showed that loss of soil moisture by evaporation occurred mainly from the upper $30 \mathrm{~cm}$ of soil, in conditions when the soil contained less water than it does at field capacity. Drying below this depth is caused by the extraction of water by the roots.

In the WATCROS model, the break point of the soil moisture function value of 0.5 $(50 \%)$ was used from May to August, and a value of $0.6(60 \%)$ was used for april and September for all plants. In the potential case of the simulation, irrigation was applied, 
1983

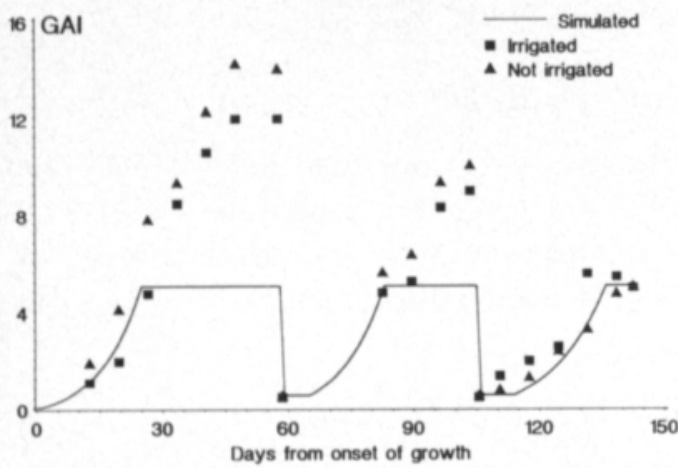

1986

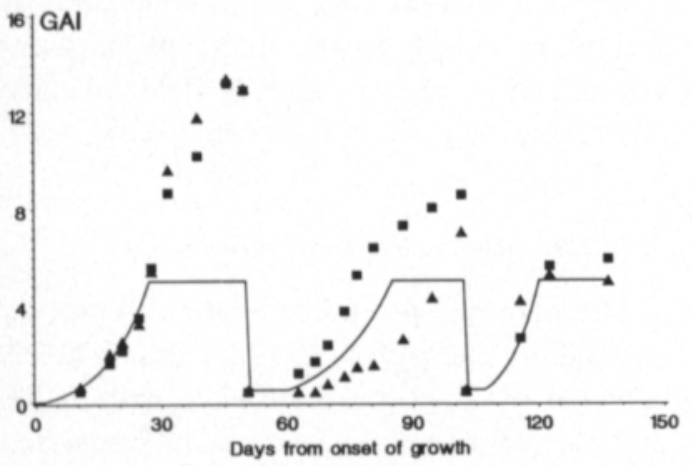

1985

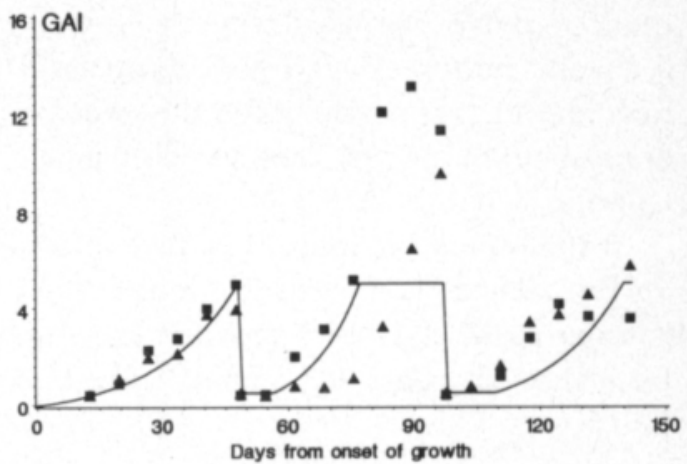

1987

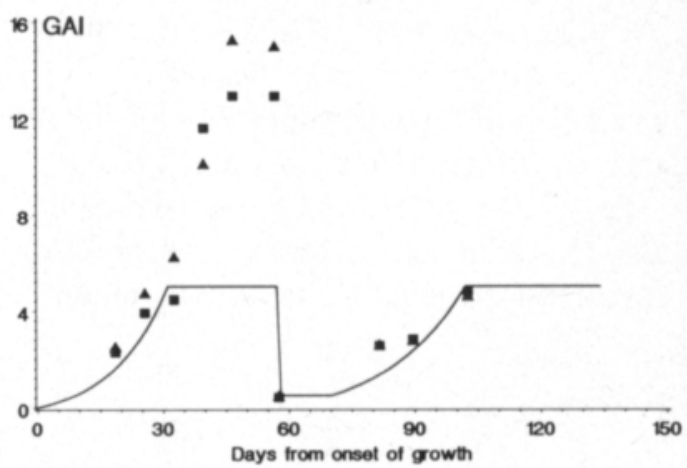

Fig. 7.3. Simulated and measured green area index (GAI) of timothy in 1983, 1985-87.

when the $40 \%$ fraction of the root zone capasity was utilized. The upper limit of water applied in an irrigation was $50 \mathrm{~mm}$.

According to SAUgier (1970), evaporation behaves in the same way as does the net radiation. When the evaporative demand is distributed between the soil $\left(\mathrm{E}_{\mathrm{s}}^{*}\right)$ and the crop $\left(\mathrm{E}_{\mathrm{c}}^{*}\right)$ and using BEER's law (see equation 7.18.), the following equations can be drawn:

(7.5) $\quad \mathrm{E}_{\mathrm{s}}^{*}=\mathrm{E}_{\mathrm{e}}^{*-K G}$

(7.6) $\quad \mathrm{E}_{\mathrm{c}}^{*}=\mathrm{E}^{*}\left(1-\mathrm{e}^{-\mathrm{KC}}\right)$

(7.7) $\mathrm{E}_{\mathrm{c}, \mathrm{g}}^{*}=\mathrm{E}^{*}\left(1-\mathrm{e}^{-K G}\right)$

(7.8) $\quad \mathrm{E}_{c, y}^{*}=\mathrm{E}_{\mathrm{c}}^{*}-\mathrm{E}_{\mathrm{c}, \mathrm{g}}^{*}$

where $\mathrm{K}=$ the extinction coefficient (equal to a net radiation of 0.6$), \mathrm{G}=$ the green area in$\operatorname{dex}(\mathrm{GAI}), \mathrm{C}=$ the crop area index (CAI), $\mathrm{E}_{\mathrm{c}, \mathrm{g}}^{*}=$ the evaporative demand of the green active crop area and $\mathrm{E}_{\mathrm{c}, \mathrm{y}}^{*}=$ the evaporative demand of the yellow, inactive, crop area.

The model operates on a daily basis; at the beginning of each step the amounts of precipitation and irrigation, called the potential interception storage $\left(\mathrm{S}_{1}^{*}\right)$, are supplied to the reservoir. JENSEN (1979) proposed that the plant can, at most, hold water equal to 0.5 $\mathrm{mm} \mathrm{H}_{2} \mathrm{O}$ on the crop surface (C) and on the crop green area $(\mathrm{G})$. The interception storage can further be distributed as follows:

(7.9) $\mathrm{S}_{1}^{*}=0.5 \mathrm{C}$

(7.10) $\mathrm{S}_{1, g}^{*}=0.5 \mathrm{G}$

(7.11) $\mathrm{S}_{1, y}^{*}=\mathrm{S}_{1}^{*}-\mathrm{S}_{1, \mathrm{~g}}^{*}$

where $\mathrm{S}_{1, \mathrm{~g}}^{*}=$ the potential interception storage of the green crop area and $\mathrm{S}_{1, y}^{*}=$ the interception storage of the yellow crop area.

The rest of $\mathrm{P}$ and I are supplied to the top- 
soil and root zone reservoir. Extra water is transferred to a through-flow reservoir, where it remains for three days if not evapotranspirated during that period. After this, water is drained out of the root zone as a deep percolation.

At the beginning, water is extracted from the topsoil at a potential rate as long as there is water in the reservoir; next it is extracted from the root zone, at a rate equal to 0.15 $\mathrm{E}_{\mathrm{s}}^{*}$.

$$
\begin{aligned}
& \mathrm{E}_{\mathrm{s}}=\mathrm{E}_{\mathrm{s}}^{*} \quad ; \mathrm{S}_{\mathrm{t}} \geq \mathrm{E}_{\mathrm{s}}^{*} \\
& \mathrm{E}_{\mathrm{s}}=0.15 \mathrm{E}_{\mathrm{s}}^{*} ; \mathrm{S}_{\mathrm{t}}<\mathrm{E}_{\mathrm{s}}^{*}
\end{aligned}
$$

where $\mathrm{E}_{\mathrm{s}}=$ the actual evaporation of the soil and $\mathrm{S}_{\mathrm{t}}=$ the actual topsoil water storage.

$\mathrm{E}_{c, g}^{*}$ extract water from the green crop area and $\mathrm{E}_{\mathrm{c}, \mathrm{y}}^{*}$ from the yellow crop area in the potential rate equal to the actual values:

$$
\begin{array}{ll}
\mathrm{E}_{c, y}=\mathrm{S}_{1, y} & ; \mathrm{S}_{1, y} \leq \mathrm{E}_{c, y}^{*} \\
\mathrm{E}_{c, y}=\mathrm{E}_{c, y}^{*} & ; \mathrm{S}_{1, y}>\mathrm{E}_{c, y}^{*} \\
\mathrm{E}_{c, g}=\mathrm{E}_{c, g}^{*} & ; \mathrm{S}_{1, g} \geq \mathrm{E}_{c, g}^{*} \\
\mathrm{E}_{c, g}=\mathrm{S}_{1, \mathrm{~g}}+\mathrm{E}_{\mathrm{T}} ; \mathrm{S}_{1, g}<\mathrm{E}_{c, g}^{*}
\end{array}
$$

where $E_{c, y}=$ the actual evapotranspiration of the yellow crop area, $\mathrm{E}_{\mathrm{c}, \mathrm{g}}=$ the actual evapotranspiration of the green crop area, $\mathrm{S}_{1, y}=$ the actual interception storage of the yellow inactive crop area, $\mathrm{S}_{\mathrm{l}, \mathrm{g}}=$ the actual interception storage of the green crop area and $\mathrm{E}_{\mathrm{T}}=$ the actual transpiration.

If the actual and potential evapotranspiration of the green crop area are the same, then $\mathrm{E}_{\mathrm{T}}=0$; but if they are not the same there is a transpiration demand:

$$
\text { (7.15) } \mathrm{E}_{\mathrm{T}}^{*}=\mathrm{E}_{\mathrm{c}, \mathrm{g}}^{*}-\mathrm{S}_{\mathrm{l,g}, \mathrm{g}}
$$

where $\mathrm{E}_{\mathrm{T}}^{*}=$ potential transpiration.

At first water is used of the through-flow reservoir and then it is extracted from the root zone. Transpiration decreases if there is less than $50 \%$ available water in the soil.

$$
\mathrm{E}_{\mathrm{T}}=\mathrm{E}_{\mathrm{T}}^{*} \quad ; \mathrm{S}_{\mathrm{r}} \geq 0.5 \mathrm{~S}_{\mathrm{r}}^{*}
$$

$$
\begin{aligned}
& \mathrm{E}_{\mathrm{T}}=\mathrm{E}_{\mathrm{T}}^{*} \frac{\mathrm{S}_{\mathrm{r}}}{0.5 \mathrm{~S}_{\mathrm{r}}^{*}} ; 0<\mathrm{S}_{\mathrm{r}}<0.5 \mathrm{~S}_{\mathrm{r}}^{*} \\
& \mathrm{E}_{\mathrm{T}}=0 \quad ; \mathrm{S}_{\mathrm{r}} \leq 0
\end{aligned}
$$

where $\mathrm{S}_{\mathrm{r}}=$ the root zone water content and $\mathrm{S}_{\mathrm{r}}^{*}=$ the whole root zone water capacity.

$\mathrm{S}_{r}^{*}$ depends on the root depth growth. The actual evapotranspiration can now be calculated:

$$
\text { (7.17) } \mathrm{E}=\mathrm{E}_{\mathrm{s}}+\mathrm{E}_{\mathrm{c}, \mathrm{g}}+\mathrm{E}_{\mathrm{c}, \mathrm{y}}
$$

The model operates as a book-keeping system on a daily basis. The initial conditions in spring are as follows: the interception reservoir is empty, the soil stays at field capacity and the through-flow reservoir is empty.

\subsection{Potential gross production}

The potential production rate of a crop is defined as "the growth rate of a closed, green crop surface, optimally supplied with water and nutrients, in a disease-free and weed-free environment under the prevailing weather conditions"' (GoudriaAN 1982). Plant production can be divided into four levels after Penning de Vries (1980). The first level is the potential plant production, when there are no limiting factors in prevailing global radiation and air temperature conditions. The WATCROS model reaches only the second level, when lack of water can decrease the DM production. The next production levels, levels three and four, include also the effect of the main nutrients $(\mathrm{N}, \mathrm{P}, \mathrm{K})$ on plant growth.

The interception of photosynthetic active radiation $(400-700 \mathrm{~nm})$ in the crop is described by BEER's law:

(7.18) $\mathrm{S}=\mathrm{S}_{\mathrm{n}} \mathrm{e}^{-k \mathrm{G}}$

where $\mathrm{S}=$ the radiative flux density below the downward accumulated GAI (G), $s_{n}=$ the radiative flux above the canopy and $\mathrm{k}=$ the extinction coefficient of PAR.

$k$ depends on the crop structure, the optical properties of leaves, solar altitude, the fraction of diffuse radiation etc. in general 
BEER's law is reliable only when the canopy stand is homogeneous and dense ( $\mathrm{k}$ is relative high). Aslyng and Hansen (1982) adopted a $\mathrm{k}$ value of 0.8 for photosynthetic active radiation (PAR), whereas KvifTE (1987) used $k=0.65$. This study used a value of 0.8 for barley and timothy and 0.65 for turnip rape. The absorption of PAR is as follows:

$$
\text { (7.19) } \mathrm{S}_{\mathrm{abs}}=\mathrm{S}_{\mathrm{v}} \times \mathrm{S}_{\mathrm{i}}\left(1-\mathrm{A}_{\mathrm{v}}\right)\left(1-\mathrm{e}^{-\mathrm{kG}}\right)
$$

where $S_{v}=$ the fraction of the photosynthetic active (or visible) radiation (PAR), $\mathrm{S}_{\mathrm{i}}=$ global radiation $(300-2500 \mathrm{~nm})$ and $\mathrm{A}_{\mathrm{v}}=$ hereof reflectivity of the crop (albedo).

In Denmark, the calculation basis for $\mathrm{S}_{\mathrm{v}}$ has been $48 \%$ of $\mathrm{S}_{\mathrm{i}}$, the albedo of dense short grass stand being 0.06 (PAR) (HANSEN et al. 1981).

The potential gross $\mathrm{CO}_{2}$ assimilation of a single leaf is used as the basis for calculations of the whole crop assimilation. The photosynthetic rate $(\mathrm{A})$ can be described as follows:

(7.20) $A=A_{m}\left(1-e^{-S, / m}\right)$

where $A_{m}=$ the rate of leaf photosynthesis at light saturation and $\mathrm{m}=$ constant.

In the WATCROS model the adopted value of $\mathrm{A}_{\mathrm{m}}$ equals $0.83 \mathrm{mg} \mathrm{CO} \mathrm{m}^{-2} \mathrm{~s}^{-1}$, which is a typical value for $\mathrm{C}_{3}$ plants. AsLyng and $\mathrm{HAN}$ SEN (1982) calculated the gross $\mathrm{CO}_{2}$ assimilation and the absorbed PAR, and computed a mean daily photosynthetic efficiency:

$$
\text { (7.21) } \mathrm{p}=\frac{\text { stored energy }}{\text { absorbed PAR }}
$$

The potential gross production is then calculated:

$$
P_{g}=c \times p \times S_{v}\left(1-A_{v}\right)\left(1-e^{-k G}\right) S_{i}
$$

where $\mathrm{c}=$ the conversion factor converting stored energy into structural plant dry matter.

AsLyng and HanSEn (1982) used selected values for mean photosynthetic efficiency (p) for different crops. We used the value of $8 \%$ for p, as did Kvifte in Norway. The conversion factor (c) converts $70 \mathrm{~g} \mathrm{DM} \mathrm{MJ}^{-1}$, which is $14.3 \mathrm{~kJ} \mathrm{~g}^{-1} \mathrm{DM}$. In Great Britain Gallagher (1976) reported a c value equal to $16.7 \mathrm{~kJ} \mathrm{~g}^{-1}$ and $\mathrm{p}=5.7 \%$ for barley carbohydrates.

\subsection{Respiration and net plant production}

Crops have many types of respiration, some of which is rather difficult to take into consideration. The WATCROS model uses only maintenance and growth respirations. Total respiration is understood to be the sum of these two respirations.

Maintenance respiration $\left(R_{m}\right)$ is a function of the dry weight of the plant, and with the rate of respiration depending upon temperature according to a temperature coefficient $\left(Q_{10)}\right.$ relation of the form:

$$
\text { (7.23) } \mathrm{R}_{2}=\mathrm{R}_{1} \times \mathrm{Q}_{10}{ }^{\left(\mathrm{t}_{2,2}-\mathrm{t}_{2,1}\right) / 10}
$$

where $\mathrm{R}=$ respiration and $\mathrm{t}_{\mathrm{a}}=$ temperature.

The $Q_{10}$ factor is stated equal to value 2 at $20^{\circ} \mathrm{C}$ (Biscoe and Gallagher 1977, Robson 1981). In the literature, the respiration coefficient $\left(\mathrm{r}_{\mathrm{m}}\right)$ values have normally been equal to $1-4 \% \mathrm{DM} \mathrm{day}^{-1}$ for various species. In the WATCROS model, $r_{\mathrm{m}}$-values for grass $4.0 \%$ day $^{-1}$ and for spring barley and turnip rape $1.5 \% \mathrm{day}^{-1}$ of the daily estimated quantity of plant dry matter were used throughout the growth period.

Besides maintenance respiration, plants also have growth respiration $\left(\mathrm{R}_{\mathrm{g}}\right)$, which is described as the factor of efficiency in conwerting carbohydrates into structural plant material. In the literature, growth respiration is reported to be $20-30 \%$ of the gross assimilation, and is independent of temperature and plant species. In the WATCROS model a value of growth respiration equal to $30 \%$ is used; this is understood as a converting factor $(0.7)$ also covering transport respiration.

Net dry matter production $\left(\mathrm{P}_{\mathrm{n}}\right)$ can now be calculated by subtracting growth and maintenance respiration from the potential gross production: 


$$
\text { (7.24) } P_{n}=P_{g}-R_{g}-R_{m}
$$

where $\mathrm{P}_{\mathrm{g}}=$ gross production (eq. 7.22), $\mathrm{R}_{\mathrm{m}}=$ maintenance respiration and $\mathrm{R}_{\mathrm{g}}=$ growth respiration.

Maintenance respiration is calculated from the stored dry weight $\left(\mathrm{W}_{\mathrm{i}-1}\right)$ and from the average daily dry matter production $(0.5 \times$ $\left.\mathrm{P}_{\mathrm{n}, \mathrm{i}}\right)$ :

(7.25) $\left.\mathrm{R}_{\mathrm{m}}=\mathrm{r}_{\mathrm{m}}\left(0.5 \times \mathrm{P}_{\mathrm{n}, 1}\right)+\mathrm{W}_{\mathrm{i}-1}\right)$

where $r_{m}=$ the maintenance respiration coefficient.

Growth respiration occurs only if there is net production:

$$
\begin{aligned}
& R_{g}=r_{g}\left(P_{g}-R_{m}\right) ; P_{g}>R_{m} \\
& R_{g}=0 \quad ; P_{g} \leq K_{m}
\end{aligned}
$$$$
\text { (7.27) } \mathrm{R}_{\mathrm{g}}=0
$$

where $r_{g}=$ the growth respiration coefficient.

When the given formulas are combined, the amount of recently assimilated carbohydrates $\left(\mathrm{P}_{\mathrm{n}, \mathrm{i}}\right)$ not yet converted into structural plant dry matter can be calculated:

(7.28) $\mathrm{P}_{n, i}=\frac{0.7\left(\mathrm{P}_{\mathrm{g}, i}-\mathrm{r}_{\mathrm{m}} \times \mathrm{W}_{\mathrm{i}-1}\right)}{1+\left(0.5 \times 0.7 \times \mathrm{r}_{\mathrm{m}}\right)} ; \mathrm{P}_{\mathrm{g}}>\mathrm{R}_{\mathrm{m}}$

(7.29) $P_{n, i}=\frac{P_{g, i}-r_{m} \times W_{i-1}}{1+\left(0.5 \times r_{m}\right)} ; P_{g} R_{m}$

the total amount of accumulated plant dry matter cannot be harvested; some of it remains in the field. As the basis of their calculations, AsLyng and HanSEn (1982) used 3 ton DM losses in the field; the same value was used in Norway (KvifTE 1987). This study also used 3 ton losses for our plant species, because of difficulties in determinations of the actual root yields in the heavy clay soil.

Simulation of the daily non-harvested DM yield from the total DM production should take into consideration the formula of plant dry matter partitioning between roots and shoots (Heemst 1986, Keulen and Seligman 1987). The daily stubble, root etc. mass loss $\left(\mathrm{W}_{\mathrm{L}, \mathrm{i}}\right)$ is calculated by using the simulated daily potential DM production $\left(\mathrm{P}_{\mathrm{n}, \mathrm{i}}\right)$ until

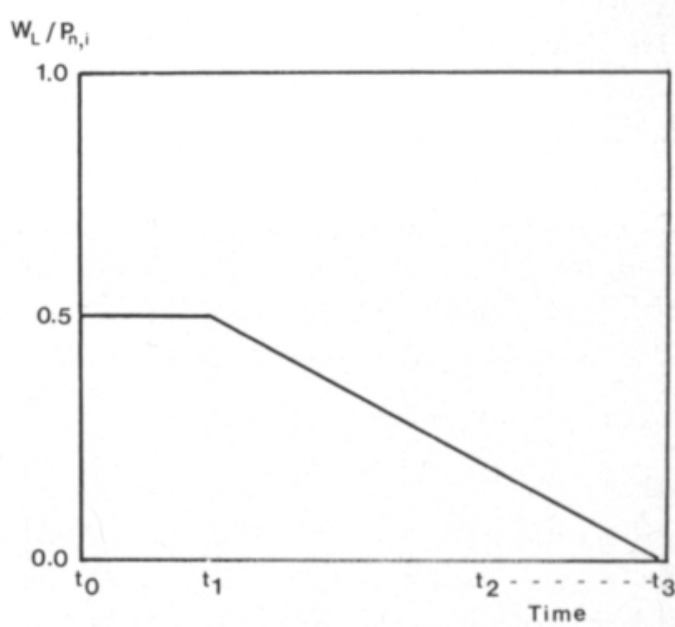

Fig. 7.4. Estimation of daily non-harvested dry matter (stubble, root, etc. mass loss) for barley and turnip rape (explanation see text).

the maximum root depth $\left(\mathrm{d}_{\mathrm{r}}\right)$ or the full 3 ton DM loss is reached:

$$
\mathrm{W}_{\mathrm{L}, \mathrm{i}}=0.5 \mathrm{P}_{\mathrm{n}, \mathrm{i}} \quad\left(\mathrm{t}_{0}<\mathrm{t} \leq \mathrm{t}_{1}\right)
$$

$$
\begin{aligned}
& \mathrm{W}_{\mathrm{L}, \mathrm{i}}=0.659-0.01 \mathrm{P}_{\mathrm{n}, \mathrm{i}} \text { (barley) } \\
& \left(\mathrm{t}_{1}<\mathrm{t} \leq \mathrm{t}_{3}\right)
\end{aligned}
$$

$$
\mathrm{W}_{\mathrm{L}, \mathrm{i}}=0.644-0.01 \mathrm{P}_{\mathrm{n}, \mathrm{i}} \text { (t. rape) }
$$

$$
\mathrm{W}_{\mathrm{L}, \mathrm{i}}=3.0 \quad\left(\mathrm{t}>\mathrm{t}_{3}\right)
$$

where $P_{n, i}=$ the daily potential net production, including the loss, $\mathrm{t}_{0}=$ the beginning of simulated potential DM production, $t_{1}=2$ weeks from $t_{0}, t_{2}=$ the time, when 3 ton DM loss is reached and $t_{3}=$ the time of maximum root depth (Fig. 7.4).

After calculations of these formulas (7.30$7.33)$, the total loss of 3 tons per hectare was reached, on average, 47 days from sowing for barley and 61 days for turnip rape. In Great Britain the maximum root yield of cereals were obtained at about 50 days from sowing (Welbank et al. (1973).

In the Danish and in the our version, DM 
loss of timothy was calculated using a linear function from the onset of growth to the maximum root depth:

(7.34) $\mathrm{W}_{\mathrm{L}, \mathrm{i}}=\frac{3.0}{\mathrm{~d}_{\mathrm{r}}}$ (timothy).

Where $d_{r}=$ the maximum effective root depth $(75 \mathrm{~cm})$.

The model continues to operate with $\mathrm{W}_{\mathrm{h}}$ until the total lost dry matter yield ( 3 tons) is reduced:

(7.35) $\mathrm{W}_{\mathrm{h}}=\mathrm{P}_{\mathrm{n}}-\mathrm{W}_{\mathrm{L}}$

where $\mathrm{W}_{\mathrm{h}}=$ the harvested dry matter yield.

Grain (barley) and seed (turnip rape) yields $\left(\mathrm{W}_{\mathrm{g}}\right)$ were calculated as follows:

(7.36) $\mathrm{W}_{\mathrm{g}}=\mathrm{H} \times \mathrm{W}_{\mathrm{h}}$

where $\mathrm{H}=$ the harvest index.

The harvest index values applied were $\mathrm{H}=0.45$ for barley and $\mathrm{H}=0.25$ for turnip rape. Timothy yield is considered to have a harvest index of $\mathrm{H}=1.0$.

\subsection{Water limited crop production}

Aslyng and Hansen (1982) used a linear relation between transpiration and potential crop production in calculating the water limited (actual) plant gross production $\left(\mathrm{P}_{\mathrm{g}}\right)$ :

(7.37) $P_{g}=\frac{E_{c, g}}{E_{c, g}^{*}} P_{g}^{*}$

where $\mathrm{E}_{\mathrm{c}, \mathrm{g}}=$ transpiration plus the evaporation of water intercepted on the green active crop surface, $E_{c, g}^{*}=$ the same in the potential case and $\mathrm{P}_{\mathrm{g}}^{*}=$ the potential gross production.

The WATCROS model does not consider the effect of water stress on the crop green area. AsLyng and HANSEn (1982) prefer gross production to net production because of difficulties and errors in estimating respiration.

Determination of actual production differs from that of potential production in only one essential aspect. Potential crop production is obtained through optimal irrigation treatment, but the actual crop production is entirely dependent on water, in the soil, available to the plant and on root depth growth. Aslyng and Hansen (1982) and Kvifte (1987) used the same maximum efficient root depth of $100 \mathrm{~cm}$. According to root measurements made in 1986 and 1987, the maximum root depth in the Finnish studies was assumed to be $75 \mathrm{~cm}$.

\section{Results and discussion}

\subsection{Barley and turnip rape}

In 1983-87 the time of the GAI development of barley was $29(27-31)$ days for the increasing phase. It was $23(17-34)$ days at $\mathrm{GAI} \geq 5$, and 33 (19-45) days in the decreasing phase. The simulation for the increasing phase of GAI, using an exponential function, succeeded well. The simulated DM production for barley was $30-45 \%$ in the increasing phase of $\mathrm{GAI}, 35-55 \%$ at $\mathrm{GAI} \geq 5$ and $15-30 \%$ in the decreasing phase of GAI.

In the prevailing weather conditions the simulated actual (water limited) DM production of barley in the experimental field was the highest in 1983 and 1984, whereas the actual DM production of turnip rape reached the maximum level in 1982 and 1983. Simulated total potential DM yields containing root, stubble etc. mass loss were $13.2-15.5$ tons per hectare for barley and 12.1-15.3 tons per hectare for turnip rape exept in 1984, when it was only 7.0 tons DM per hectare.

The simulated development of actual dry matter production for barley was somewhat greater than the values measured (Fig. 8.1). The difference was even greater for turnip rape than for barley (Fig. 8.2). Such behaviour is explained by the fact that the WATCROS model takes into consideration only the limits in water use, but not the excess of water in the soil. In Finnish climatic and soil conditions, root development seems to be more restricted than in the Danish conditions. Soil 
1982

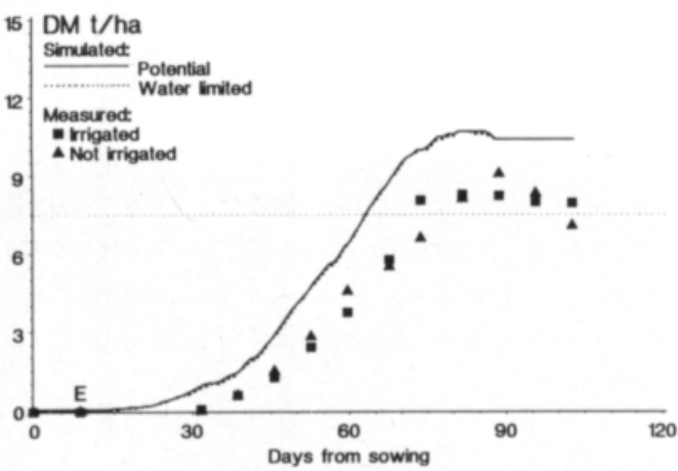

1984
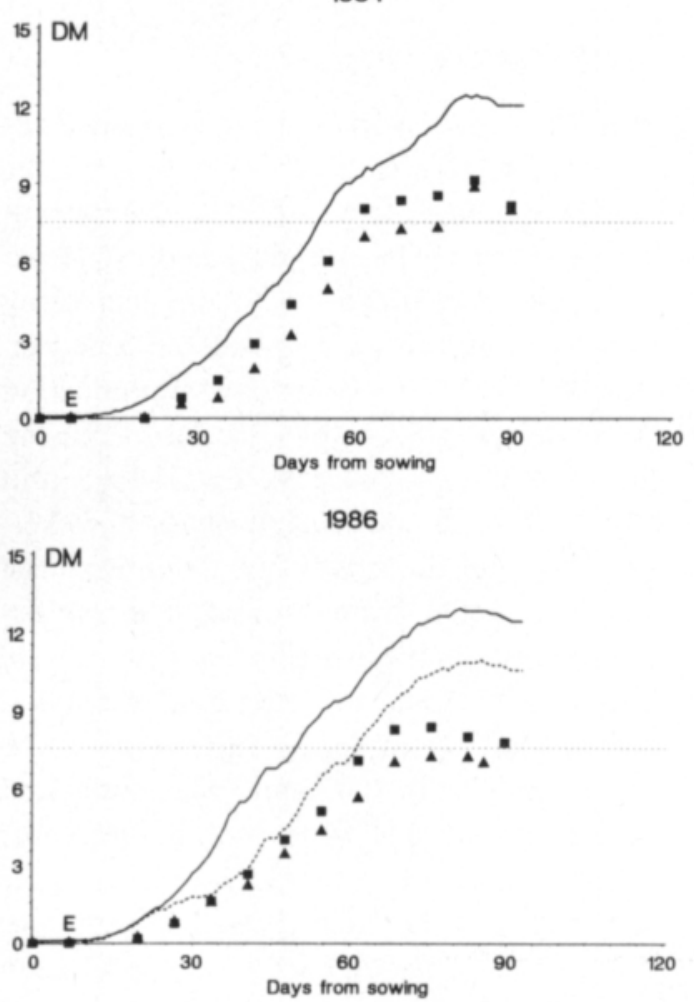

1983

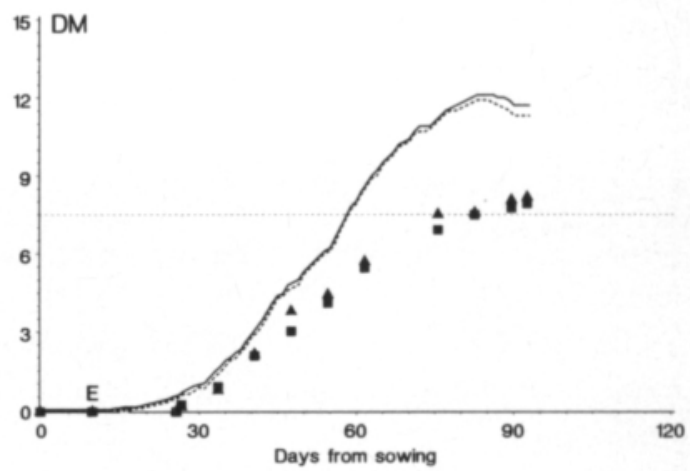

1985

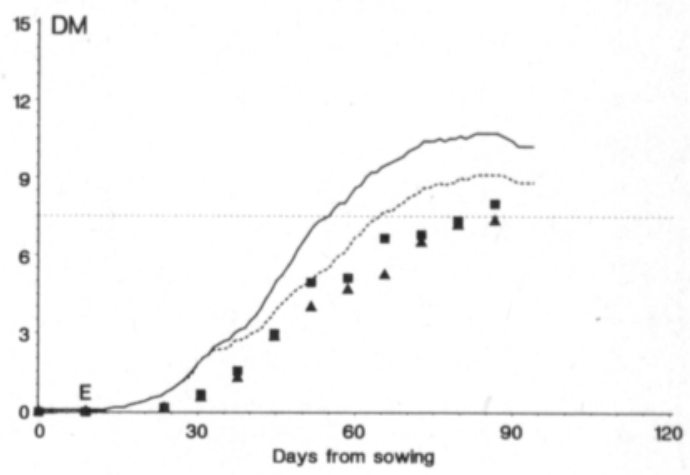

1987

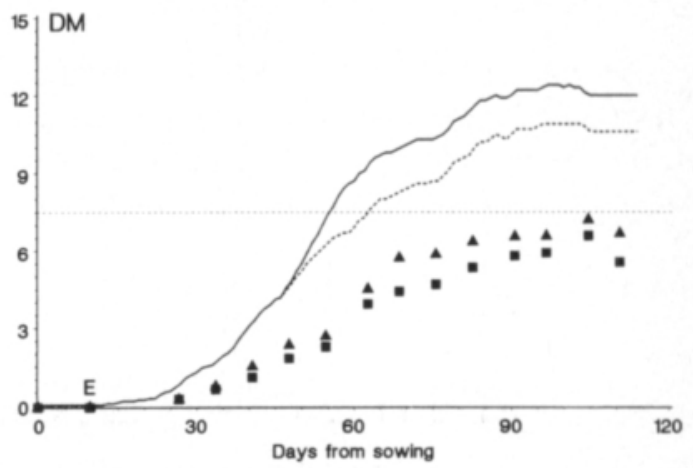

Fig. 8.1. Above ground dry matter (DM) production of barley in 1982-87. E =emergence day.

conditions and root development seem to lead the plant to a lower PAR use of stand in Finland than in Denmark.

In some years the grain yields at Jokioinen district were higher than the simulated potential grain yields in the experimental field (Tables 8.1 and 8.2 ). In such cases harvested yields that were greater than simulated poten- tial ones may be the result of differences in sowing time, the development of GAI in relation to incoming radiation and the values of the harvest index. For example, in the first study year (1982), the crop surface development of barley was poor, which decreased the simulated yield. In 1987, though generally a rainy and cool year, the development of GAI 
1982

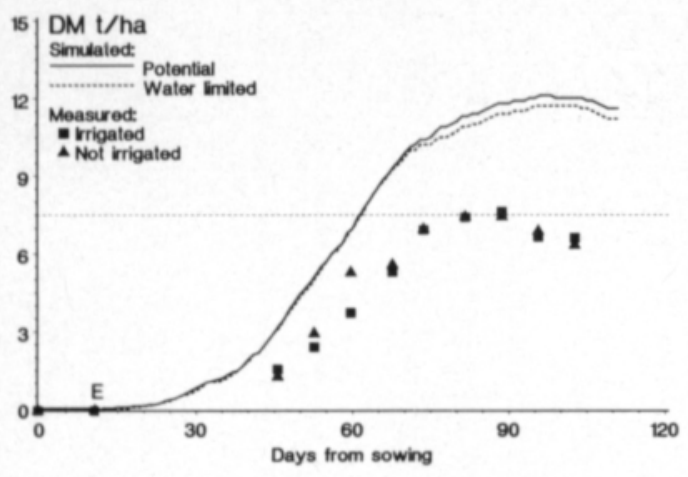

1984

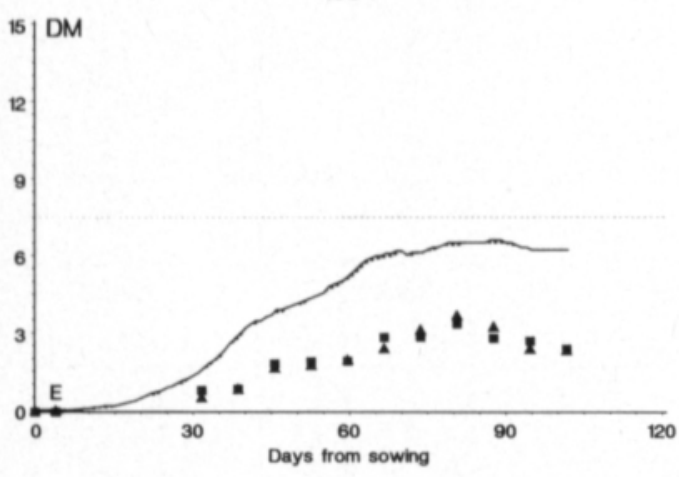

1986

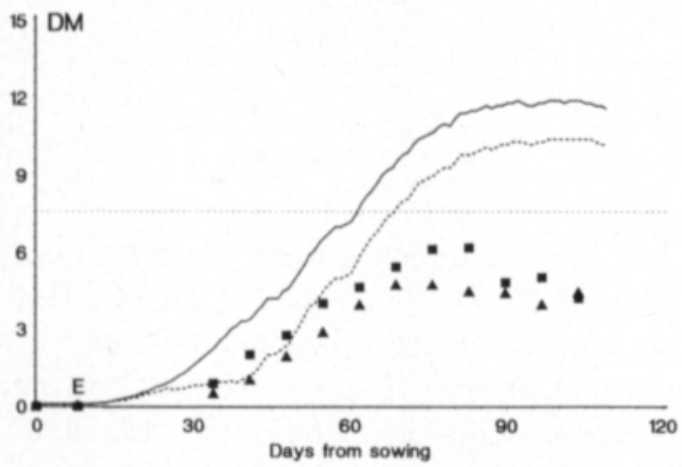

1983

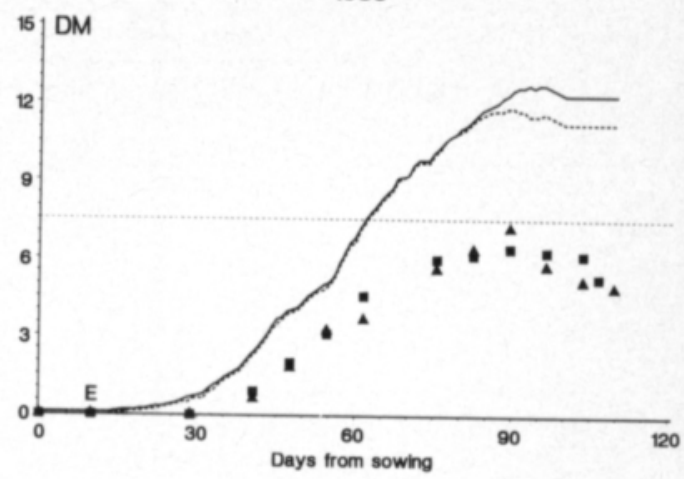

1985

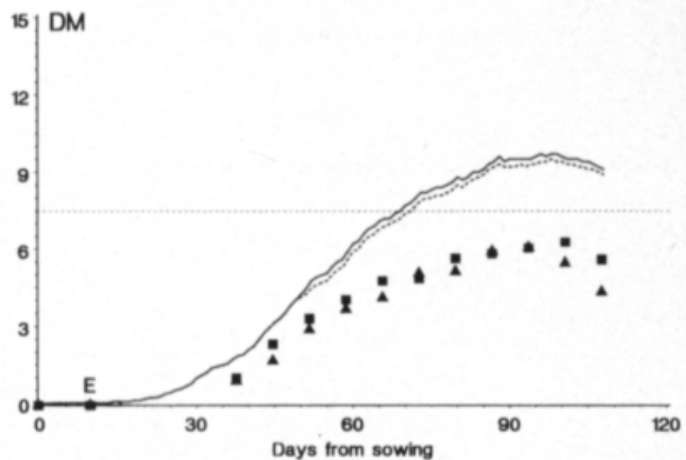

1987

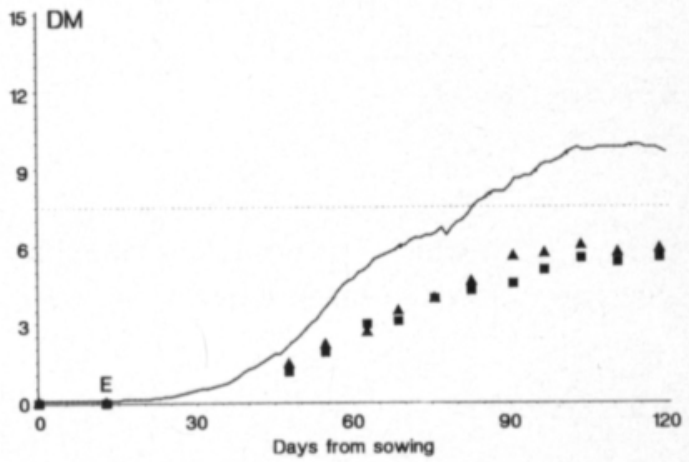

Fig. 8.2. Above ground dry matter (DM) production of turnip rape in 1982-87. E=emergence day.

was great due to the high incoming radiation in July, and the simulation of potential DM production of barley was also high, 15.0 tons per hectare. The measured DM production remained low due to the excess of water and low temperature during the filling period of grain.

According to the results of the simulated potential yield, irrigation was meaningful dur- ing the last three tests years (1985-87) for barley but only in 1983 and 1986 for turnip rape. The simulated model introduced requirements for irrigation; these varied from 30 to $165 \mathrm{~mm}$ in the growing season for barley and $15-170 \mathrm{~mm}$ for turnip rape. In the rainy seasons of 1984 and 1987 , occasionally there was too much water in the field for crop produc- 
Table 8.1. Production results of Pomo barley including $15 \%$ moisture at Jokioinen (grain tons/ha).

\begin{tabular}{|c|c|c|c|c|c|c|c|c|}
\hline \multirow[t]{3}{*}{ Year } & \multicolumn{4}{|c|}{ Measured: } & \multicolumn{4}{|c|}{ Simulated: } \\
\hline & \multirow[t]{2}{*}{ KVO } & \multirow[t]{2}{*}{ KJO } & \multicolumn{2}{|c|}{ Climatic field } & \multicolumn{2}{|c|}{ Potential } & \multicolumn{2}{|c|}{ Actual } \\
\hline & & & 1 & 2 & MAK & PEN & MAK & PEN \\
\hline 1982 & 7.5 & 7.3 & 3.8 & 4.7 & 5.5 & 5.5 & 5.5 & 5.4 \\
\hline 1983 & 4.6 & 7.3 & 4.9 & 5.2 & 6.2 & 6.2 & 6.0 & 6.1 \\
\hline 1984 & 3.3 & 4.2 & 4.2 & 4.1 & 6.3 & 6.3 & 6.3 & 6.3 \\
\hline 1985 & 5.6 & 6.4 & 3.9 & 4.6 & 5.4 & 5.4 & 4.6 & 5.3 \\
\hline 1986 & 4.0 & 5.8 & 5.4 & 4.3 & 6.6 & 6.6 & 5.6 & 5.8 \\
\hline 1987 & 4.2 & 4.6 & 3.2 & 3.2 & 6.4 & 6.4 & 5.6 & 6.2 \\
\hline
\end{tabular}

KEY: Department of Agricultural Centre:

$\mathrm{KVO}=$ Crop Science, $\mathrm{KJO}=$ Plant Breeding

Formula of Potential evapotranspiration (PET):

MAK $=$ Makkink, $\mathrm{PEN}=$ Penman

Plot:

1 = Irrigated, 2 = Non-irrigated

Table 8.2. Production results of Span turnip rape (Kova 1987) including $9 \%$ moisture at Jokioinen (seed tons/ha)

\begin{tabular}{|c|c|c|c|c|c|c|c|c|}
\hline \multirow[t]{3}{*}{ Year } & \multicolumn{4}{|c|}{ Measured: } & \multicolumn{4}{|c|}{ Simulated: } \\
\hline & \multirow[t]{2}{*}{ KVO } & \multirow[t]{2}{*}{ KJO } & \multicolumn{2}{|c|}{ Climatic field } & \multicolumn{2}{|c|}{ Potential } & \multicolumn{2}{|c|}{ Actual } \\
\hline & & & 1 & 2 & MAK & PEN & MAK & PEN \\
\hline 1982 & 2.7 & 1.9 & 2.1 & 1.9 & 3.2 & 3.2 & 3.1 & 3.0 \\
\hline 1983 & 2.8 & 2.6 & 1.8 & 1.6 & 3.4 & 3.4 & 3.1 & 3.3 \\
\hline 1984 & 1.9 & 0.7 & 1.0 & 0.7 & 1.6 & 1.5 & 1.6 & 1.6 \\
\hline 1985 & 2.0 & - & 1.7 & 1.9 & 2.5 & 2.5 & 2.4 & 2.5 \\
\hline 1986 & 1.8 & - & 1.7 & 1.5 & 3.2 & 3.2 & 2.7 & 2.9 \\
\hline 1987 & 2.0 & 2.4 & 1.4 & 1.6 & 2.6 & 2.6 & 2.6 & 2.6 \\
\hline
\end{tabular}

KEY: (see Table 8.1)

tion, a factor which was not taken into consideration in this growing model.

\subsection{Timothy}

For timothy, the real annual development of crop surface was simulated separately for each of the cuts. ASLYNG and HANSEN (1982) used the long term mean development of GAI for Italian ryegrass. The maximum values measured for GAI were often much greater than the value, $G_{m}=5$, used in the simulation model. In Norway KvifTE (1987) used the value of $G_{m}=7$ for the first cut and $G_{m}=5$ for the second cut in the simulation of GAI of timothy.

The total DM yields measured for timothy were only about $60 \%$ of the simulated ones (Table 8.3). The simulation of timothy DM production succeeded best in 1987 , but was still unsatisfactory (Fig. 8.3). Timothy had the best production conditions in 1983. The simulation model introduced the need for irrigation for the whole growth period; it varied from 55 to $150 \mathrm{~mm}$ per year. In the field, irrigated plots had better yields than the nonirrigated plots only in 1985 and 1986, which were relatively dry years.

The total annual simulated poatential DM yields of timothy were $15.4-20.2$ tons per ha. One reason for the differences between the simulated grass dry matter yields and the actual measured DM yields may have been the effect of soil temperature, which was a 


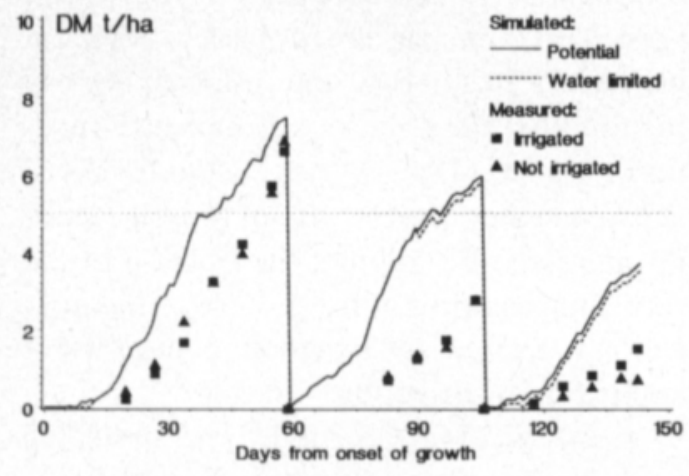

1986

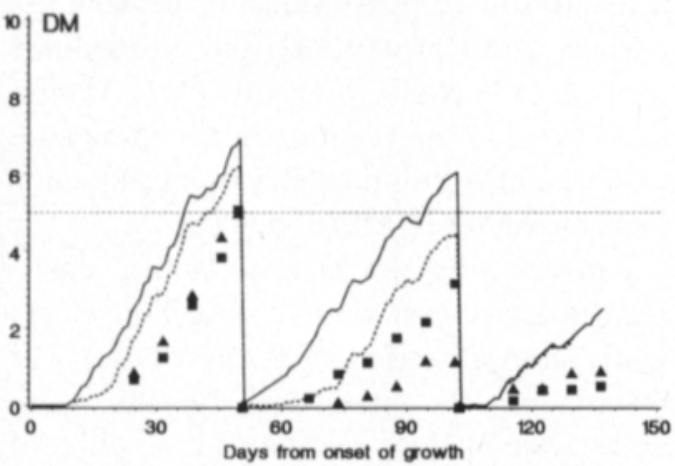

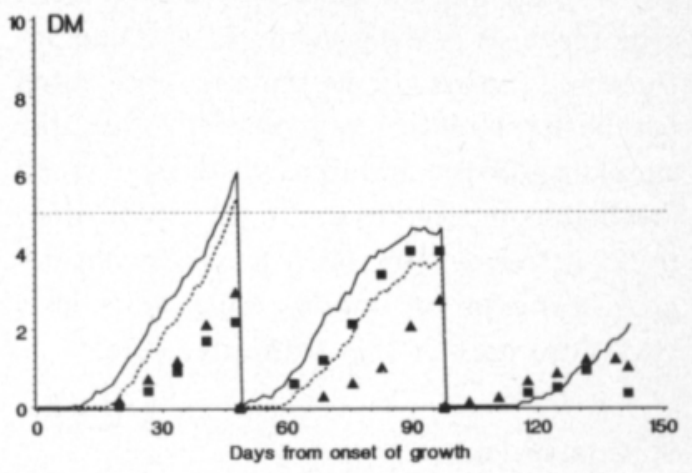

1987

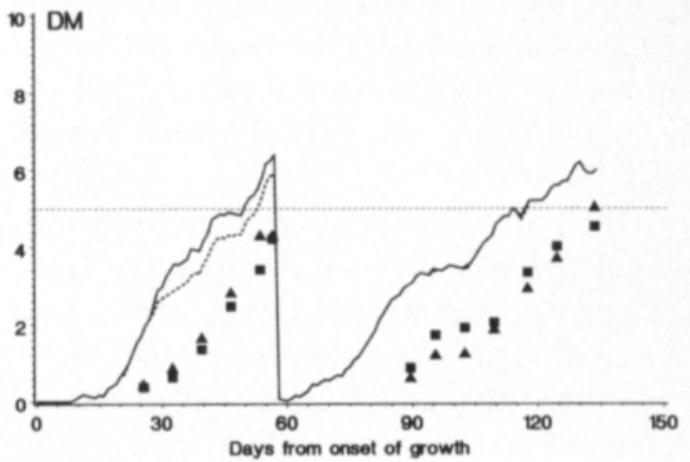

Fig. 8.3. Above ground dry matter (DM) production of timothy in 1983, 1985-87.

Table 8.3. Production results of Timothy grass at Jokioinen (tons DM/ha).

\begin{tabular}{|c|c|c|c|c|c|c|c|c|}
\hline \multirow[t]{3}{*}{ Year } & \multirow{3}{*}{$\begin{array}{c}\text { End } \\
\text { cut }\end{array}$} & \multicolumn{3}{|c|}{ Measured: } & \multicolumn{4}{|c|}{ Simulated: } \\
\hline & & \multirow[t]{2}{*}{ KVO } & \multicolumn{2}{|c|}{ Climatic field } & \multicolumn{2}{|c|}{ Potential } & \multicolumn{2}{|c|}{ Actual } \\
\hline & & & 1 & 2 & MAK & PEN & MAK & PEN \\
\hline \multirow[t]{4}{*}{1983} & I & 5.8 & 6.6 & 6.9 & 7.5 & 7.5 & 7.5 & 7.5 \\
\hline & II & 5.2 & 2.8 & 2.8 & 6.0 & 6.0 & 5.9 & 5.9 \\
\hline & III & 1.4 & 1.5 & 0.8 & 3.7 & 3.7 & 3.5 & 3.6 \\
\hline & Sum & 12.4 & 11.0 & 10.4 & 17.2 & 17.2 & 16.9 & 16.9 \\
\hline \multirow[t]{4}{*}{1985} & I & 3.9 & 2.2 & 3.0 & 6.1 & 6.1 & 5.4 & 5.4 \\
\hline & II & 3.7 & 4.1 & 2.8 & 4.6 & 4.6 & 3.9 & 4.0 \\
\hline & III & - & 1.0 & 1.2 & 2.1 & 2.1 & 2.1 & 2.1 \\
\hline & Sum & 7.6 & 7.3 & 6.9 & 12.8 & 12.8 & 11.4 & 11.5 \\
\hline \multirow[t]{4}{*}{1986} & 1 & 4.7 & 5.1 & 5.0 & 7.0 & 7.0 & 6.3 & 6.4 \\
\hline & II & 2.3 & 3.2 & 1.2 & 6.1 & 6.1 & 4.5 & 4.7 \\
\hline & III & - & 0.6 & 0.9 & 2.5 & 2.5 & 2.5 & 2.5 \\
\hline & Sum & 7.0 & 8.9 & 7.1 & 15.6 & 15.7 & 13.3 & 13.6 \\
\hline \multirow[t]{3}{*}{1987} & I & 3.5 & 4.3 & 4.3 & 6.4 & 6.4 & 5.9 & 6.3 \\
\hline & II & 4.4 & 4.6 & 5.1 & 6.0 & 6.0 & 6.0 & 6.0 \\
\hline & Sum & 7.9 & 8.9 & 9.4 & 12.4 & 12.4 & 11.9 & 12.3 \\
\hline
\end{tabular}

KEY: (see Table 8.1) 
growth-reducing factor in one to two weeks after the onset of the growth period. Other influencing factors are the same as those noted for barley and turnip rape. However, the simulated second and third yields were much too high compared to the first yield of timothy. The reason for this may be the natural growth rhythm of timothy, which includes a very slow start of regrowth after cuts.

\section{Conclusions}

The Water Balance and Crop Production Simulation (WATCROS) model of Danish origin was tested in Finnish climatic and soil conditions as a part of the Nordic Project (NKJ-47).

Different from the WATCROS model, the simulated crop surface was determined as the real development of GAI, owing to the importance of GAI in the absorbance of PAR.

In the simulation model of potential evapotranspiration, modified versions of Makkink (1957) and Penman (1956) were tested. As a result, the calculated values of potential evapotranspiration by MAKKINK or Penman led to the same result of the simulated actual DM yields of the three studied plant species. The MAKKINK was used as the basis of calculations.

The constants used in the WATCROS model are as follows: gross $\mathrm{CO}_{2}$ single leaf assimilation $=0.83 \mathrm{mg} \mathrm{m}^{-2} \mathrm{~s}^{-1}$; albedo $=6 \%$ of PAR; the factor converting stored energy to plant structural $\mathrm{DM}=70 \mathrm{~g} \mathrm{DM} \mathrm{MJ}^{-1}$; the $\max . \mathrm{GAI}=5$; the harvest index, $=0.45$ for barley, $=0.25$ for turnip rape and $=1.0$ for timothy; the extinction coefficient $=0.8$ for timothy and barley and $=0.65$ for turnip rape; the extinction coefficient for net radiation $=0.6$; the growth respiration coefficient $=$ $30 \%$; the maintenance respiration coefficient $=1.5 \%$ for barley and turnip rape and $=4.0 \%$ for timothy; the maintenance respiration $\mathrm{Q}_{10}=2$; $\mathrm{PAR}=48 \%$ of global radiation; gross photosynthetic efficiency $=8 \%$; the stubble, root etc. mass loss in harvest $=3$ ton DM per hectare; the maximum effective root depth $=75 \mathrm{~cm}$; the speed of root depth growth $=1.3 \mathrm{~cm}$ per day for barley, $=1.2 \mathrm{~cm}$ per day for turnip rape and $=0.7 \mathrm{~cm}$ per day for timothy; the point of soil moisture function $=0.5$ for May-August, $=0.6$ for April and September; the capasity of topsoil evaporation reservoir $=10 \mathrm{~mm}$; the fraction of the root zone capasity utilized $=0.40$, when irrigation is applied; the largest amount of water applied in an irrigation $=50 \mathrm{~mm}$.

In the WATCROS model the simulated water limited crop production fit well to the actual measured crop production in Denmark (ASLYNG and HANSEN 1982) and, in modified form, also in Norway (KvifTE 1987). In Finland the Danish version of the model introduced higher simulated actual production than measured in actual yields.

Reasons why the Danish model, unless modified, does not seem to fit to Finnish climatic and soil conditions are as follows: The Danish model consentrates on the water limited production conditions, excluding the excess of water in the soil and in the plant. The maximum efficient root depth growth in Finland $(75 \mathrm{~cm})$ is more limited than in Denmark $(100 \mathrm{~cm})$. Also the daily depth growth of the roots in Finland was lower (from 0.7 to $1.3 \mathrm{~cm}$ ) than in Denmark $(1.5-2.0 \mathrm{~cm}$ per day). The gross photosynthetic efficiency $8 \%$ from PAR, used in Danish model seems to be an overestimate in the Finnish conditions, owing to soil type and excess of water in the soil and in the plant, but also to the temperature conditions in shoot growth, and especially, in root growth.

The Finnish studies on simulation models occurred during growing seasons characterized by heavy amounts of precipitation. The WATCROS model did not include possible losses of nitrogen in the calculations. Water, PAR efficiency and possibly nitrogen should be taken into consideration when constructing a production model for Finnish climatic and soil conditions.

Acknowledgements. This paper is connected with a joint Nordic project, NKJ-47, 'Effect of climatological 
factors on crop growth and production in Nordic Countries'. We wish to thank computer operator R. Merkkiniemi and the staff of the Department of Crop Science of the Agricultural Research Centre and the staff of the Meteorological Observatory at Jokioinen and computer operator, T. Koskela, M. Sci. of the Finnish Meteoro- logical Institute in Helsinki for their important assistance. We are also grateful to Dr. T. Karvonen of the Finnish Field Drainage Centre in Helsinki for inspiring discussions. We thank the Academy of Finland and the Ministry of Agriculture and Forestry for financing the study.

\section{References}

Ansalehto, A., ElomaA, E., Nordlund, A. \& PilliSıнvOLA, Y. 1985. Maatalouden sääpalvelukokeilu kesällä 1984. MTTK, Tiedote 2/85. 127 s. Jokioinen.

Astyng, H.C. 1976. Klima, Jord og Planter. Kulturteknik I, 5. Den. kgl Veter.- og Landbohøsk. 368 p. Køpenhavn.

Astyng, H.C. \& Hansen, S. 1982. Water balance and Crop production simulation. Hydrotechnical Laboratory. The Royal Veterinary and Agricultural University. 200 p. Copenhagen.

Biscoe, P.V. \& Gallagher, J.N. 1977. Weather, dry matter production and yield. (Eds) Landsberg and Cutting. Environmental Effects on Crop Physiology. p. 75-100. Academic Press. New York.

Denmead, O.T. \& Shaw, R.H. 1962. Availability of soil water to plants as affects by soil moisture content and meteorological conditions. Agron. J. 54: 358-390.

ElomaA, E. 1987. Experiences in automation of agrometeorological observations in Finland. Sixth Symposium on Meteorological Observations and Instrumentation of the Amer. Meteorol. Soc., January 12-16, 1987. 4 p. New Orleans, Louisiana.

— \& Puıı, S. 1985. Variationer i globalstrålning, effectiva temperatursumma, nederbörd, potentiella evapotranspiration och nederbördsunderskott i relation till văxtproduktion i Södra Finland. NJF-seminarium 77: 19-27. Uppsala 24-25 September 1985. Jordbruksmeteorologi. Aktuell och potentiell växtproduktion. Nordiska Jordbruksforskarens Forening. Uppsala.

-, Ilola, A. \& Pulli, S. 1986. Final report of project NKJ-47 in Finland. $11(+3)$ p. Agricultural Research Centre. Jokioinen.

Feddes, R.A., Kowalik, P.J. \& Zaradny, H. 1978. Simulation of field water use and crop yield. $189 \mathrm{p}$. Centre for Agricultural Publishing and Documentation. Wageningen.

Gallagher, J.N. 1976. The Growth of Cereals in Relation to Weather. Ph. D. Thesis. University of Nottingham. 158 p. Nottingham.

GoudriaAn, J. 1982. Potential production process. (Eds) Penning de Vries and van Laar. Simulation of plant growth and crop production. p. 98-113. Centre for Agricultural Publishing and Documentation. Wageningen.
Hankimo, J. 1964. Some computations of the energy exchange between the sea and the atmospheric in the baltic area. Finn. Meteorol. Office Contr. 57: 1-26.

Hansen, S., Jensen, S.E. \& Astrng, H.C. 1981. Jordbrugsmeteorologiske observationer, statistisk analyse og vundering 1955-1979. Hydroteknisk Laboratorium. Den kgl. Veter. - og Landbohøsk. 414 p. København.

HeEmst, H.D.J. 1986. Crop phenology and dry matter distribution. (Eds) Keulen and Wolf. Modelling of agricultural production: weather, soils and crops. p. 27-40. Centre for Agricultural Publishing and Documentation. Wageningen.

Heinonen, R. 1985. Soil Management and Crop Water Supply. 4th ed. Dept. Soil Sci. Sweden University Agric. Sci. 103 p. Uppsala.

JAKOBSEN, B.F. 1976. Jord, rodvaekst og stofoptagelse. (Eds) Hansen, Jakobsen og Jensen. Simuleret planteproduktion. Den kgl. Veter.- og Landbohøsk. 34 s. København.

JENSEN, S.E. 1979. Model ETFOREST for calculating actual evapotranspiration. (Ed.) Halldin. Comparison of forest water use and energy exchange models. Int. Society for Ecological Modelling (ISEM) p. 165-172. Copenhagen.

Keulen, H. Van \& Seligman, N.G. 1987. Simulation of water use, nitrogen nutrition and growth of a spring wheat crop. 310 p. Centre for Agricultural Publishing and Documentation. Wageningen.

Kulmala, A. 1970. Heat balance of the earth's surface at Jokioinen (60.8 N, 23.5 E), Summer 1968. 69 p. Finn. Meteorol. Office Contr. 74. Helsinki.

Kvifte, G. 1987. Crop Production and Growth Model for Cereals, Rape and Grass at Aas, Norway. Acta Agric. Scand. 37: 137-158.

LONG, I.F. \& FrenCH, B.K. 1967. Measurement of soil moisture in the field by neuthron moderation. J. Soil. Sci. 18: 149-166.

MADSEN, H.B. 1978. Jordbundskartering og bonitering. Belyst ved hjælp af jordens vandretention, bygs rodudvikling og simuleret planteproduktion. Folio Geographica Danica X, 5. Licentiatafhandling, Københavns Universitet. 183 s. +6 bilag. København.

Mаккіnк, G.F. 1957. Ekzameno de la formulo de Penman. Repr. Neth. J. agric. Sci. 5: 290-305. 
Morton, F.I. 1975. Estimating evaporation and transpiration from climatological observations. J. Appl. Meteorol. 14,4: 488-497.

Newman, E.I. 1966. A method of estimating the total length of root in a sample. J. appl. Ecol. 3: 139-145.

Penman, H.L. 1956. Evapotranspiration: An introductory survey. Neth. J. agric. Sci. 4: 8-29.

Penning De Vries, F.W.T. 1980. System analysis and models of crop production. (Eds) Penning de Vries and van Laar. Simulation of plant growth and crop production. p. 9-19. Centre for Agricultural Publishing and Documentation. Wageningen.

RoBson, M.J. 1981. Respiratory efflux in relation to temperature of simulated swards of perennial ryegrass with contrasting soluble carbohydrate contents. Ann. Bot. 48: $269-273$.

SaArinen, J., Pulli, S. \& ElomaA, E. 1986. Sảäkentän käyttő kasvin potentiaalisen sadon määrittămisessä. Suomen Maatal.tiet. Seuran Tied. No 7: 90-97.

SaAval.ainen, J. \& Rintanen, S. 1986. Uusi kenttämittausmenetelmä kyllästyneen maan hydraulisen johtavuuden mittaukseen. Vesitalous 3: 31-34.

SAlonen, M. 1949. Tutkimuksia viljelykasvien juurten sijainnista Suomen maalajeissa. Suomen Maatal.tiet. Seuran Julk. 70, 1: 1-91.

Saugier, B. 1970. Micrometeorology on Crops. and Grasslands. (Eds) Landsberg and Cutting. Environmental Effect on Crop Physiology. p. 39-55. Academic Press. London.

Welbank, P.J., GıbB, M.J., Taylor, P.J. \& Willıams, E.D. 1973. Root growth of cereal crops. Roth. Exp. Stat. Report for 1973 part 2: 26-66.

Ms received January 29:, 1988,

\section{SELOSTUS}

\section{Tanskalaisen kasvumallin testaaminen ohralla, rypsillä ja timoteilla Suomen olosuhteissa}

\author{
A. Ilola, ${ }^{1}$ E. Elomaa ${ }^{2}$ and S. Pulli ${ }^{3}$
}

\section{Kasvinviljelyosasto, Maatalouden tutkimuskeskus 31600 Jokioinen \\ 2 Havaintotekninen toimisto, Ilmatieteen laitos PL 503 00101 Helsinki}

${ }^{3}$ Kasvinjalostusosasto, Maatalouden tutkimuskeskus 31600 Jokioinen

Biologis-meteorologinen aineisto kerăttiin Jokioisissa vuosina $1982-87$. Ohran, rypsin ja timotein potentiaa- linen ja vesirajoitteinen kuiva-ainesato simuloitiin tanskalaisen WATCROS-mallin mukaan.

Tärkeimpiä biologisia mittauksia olivat kasvustoalan (GAI), kuiva-ainesadon, juurten kasvun ja maan kosteuden viikoittainen seuranta sekă puintiajankohdan satoanalyysit sekä sadetetuilta ettả sadettamattomilta lohkoilta. Simuloinnissa tarvitut ja myős kentältă mitatut meteorologiset parametrit olivat puolestaan päivittäinen auringon kokonaissäteily, ilman lämpötila ja sadanta.

WATCROS-mallilla simuloidut kuiva-ainesadot olivat yleensă suurempia kuin koekentaaltă saadut sadot. Jatkotutkimuksissa tulisikin selvittaaă fotosynteettisesti aktiivisen auringon säteilyn tehokkuus Suomen kasvuoloissa, sekä maan liiallisen märkyyden ja kasveille käyttökelpoisen typen huuhtoutumisen vaikutus kasvien kasvuun ja tuotantoon. 